\title{
Recent advances using gold nanoparticles as a promising multimodal tool for tissue engineering and regenerative medicine
}

\author{
Stephanie Vial, ${ }^{*}$ Rui L. Reis, J. Miguel Oliveira \\ 3B's Research Group, AvePark - Parque de Ciência e Tecnologia, Zona Industrial da Gandra, 4805-017 Barco, Guimarães, Portugal \\ ICVS/3B's - PT Government Associate Laboratory, Braga, Guimarães, Portugal
}

\section{A R T I C L E IN F O}

Article history:

Received 30 October 2015

Accepted 27 March 2016

Available online $\mathrm{xxx}$

\section{Keywords}

Gold nanoparticle

Tissue engineering

Regenerative medicine

Scaffold

Stem cells

\section{Introduction}

Tissue Engineering and Regenerative Medicine (TERM), a multidisciplinary field including engineering, biology, and medicine, has been promising to develop viable therapeutic alternatives to organ and tissue transplantation. TERM thus holds great attention to tackle the clinical tasks by repairing, replacing or regenerating damaged tissues with functional engineered counterparts [1-3].

The human organs and tissues are composed of cells that can grow, proliferate and differentiate into desired cell type onto the 3D scaffold materials. In TERM, the use of stem cells such as mesenchymal stem cells and adipose-derived stem cells to differentiate into different cell lineages such as chondrocytes (cartilage cells), osteoblasts (bone cells), adipocytes (fat cells) have been considered as a great choice and continue to be significantly used [4]. However, to date, the limitations encountered for the regeneration of artificial tissue (bone, cartilage, skin, cardiac/skeletal muscle, nerve) are mainly due to poor mechanical and cell adhesive properties of scaffold, inefficient cell growth and differentiation at the defect site, as well as unstable growth factors to stimulate cell growth $[5,6]$.

TERM has the willing to develop a system that will be able to enhance the regeneration of the tissue, by it means a system that will deliver growth factors and improve mechanical properties of scaffold, providing to the cells a suitable environment to differentiate. Within this challenge in mind, researchers attempt to introduce new scientific and technology concepts to revolutionize this clinical realm. To date, nanotechnology has emerged as a promising tool and has made a major impact in modern science $[7,8]$. In mid-1990 s, scientists start to

\footnotetext{
* Corresponding author at: CNRS, Aix-Marseille Université, Centrale Marseille,
} Institut Fresnel, UMR 7249, 13013 Marseille, France.

Email address: stephanie.vial@fresnel.fr (S. Vial) actively exploit the remarkable features of nanotechnology for various biological and medical applications and since the advances in nanotechnology for medicine continue to grow with the development of novel biomedical strategies $[9,10]$. With the aim to improve the present progress in TERM, a tremendous number of studies have successfully exploited polymeric and inorganic nanoparticles (NPs) [11-14]. Among those, gold nanoparticles (AuNPs) are one of the most promising and explored tools in nanomedicine. AuNPs have been widely used as therapeutic agents (drug delivery system [15], photothermal therapy [16]), diagnosis agents [17] and imaging agents [18,19]. Their nanoscale size, which meets the dimension of biological compounds, their easy preparation, high surface area, easy functionalization make them particularly interesting to accomplish the duties related to TERM. Besides, they present remarkable physicochemical properties, which are different from those of the corresponding bulk materials, and make them unique compared to classical NPs such as liposomes, polymeric NPs, and protein-based NPs. These physicochemical properties derive from the localized surface plasmon resonance (LSPR), a collective oscillation of the conduction electrons that typically occurs in the visible to near-infrared (NIR) region spectrum and can be easily detected by NIR-UV-visible spectrometry or even by eye [20]. Therefore, the mission of AuNPs in TERM is to act as a multimodal tool in order to enhance scaffold properties, cell differentiation and intracellular growth factor delivery (Fig. 1), while monitoring in real-time cellular events

Despite the large advances made in cancer research using AuNPs, their use in TERM is still in its infancy. However, their potential in this area is away analogous to cancer theranostics approaches. Hence, the asset of exploiting AuNPs as promising multimodal tools for TERM will be discussed while supporting some new trends in the cancer field. Firstly, it is reported the preliminary strategies for tuning the properties of AuNP's, by means of synthesis, functionalization and cell-AuNPs interactions, which are requested for the preparation 


\section{TISSUE ENGINEERING AND REGENERATIVE MEDICINE MEET GOLD NANOPARTICLES}

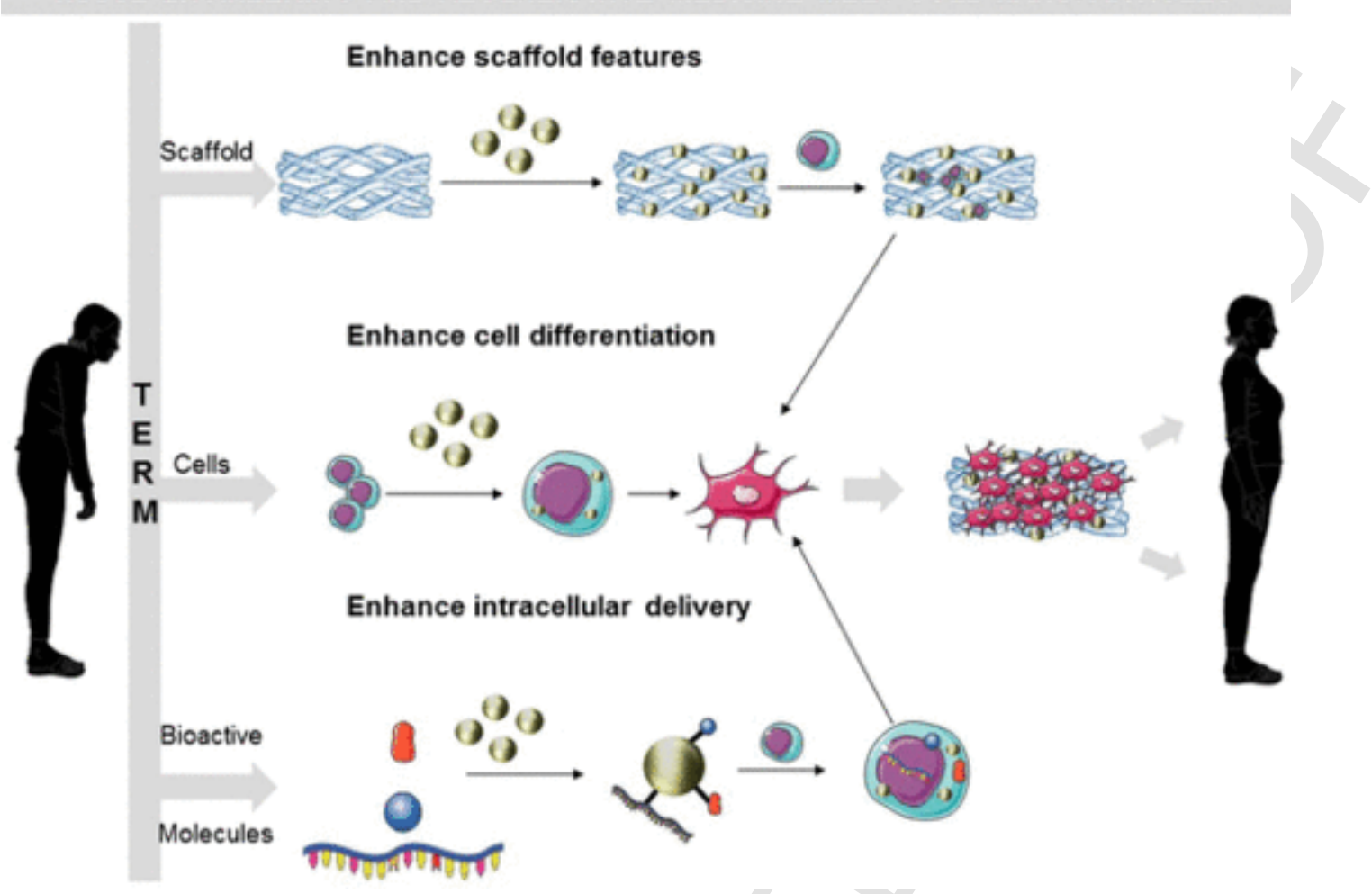

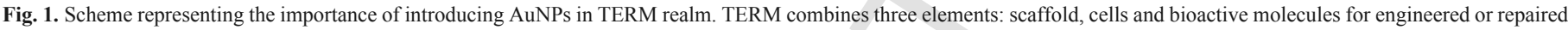

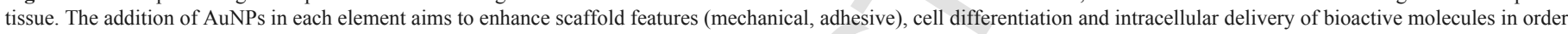
to bring an ideal microenvironment for the regeneration of the damaged tissue.

of a biocompatible nanomaterial. Then, the recent works using AuNPs as individual or multifunctional tool for drug delivery, diagnosis and imaging in TERM, specifically related to stem cell research is overviewed. Finally, the recent advances using AuNPs to enhance stem cells differentiation for bone tissue engineering, and to improve mechanical and adhesive properties, and favored nanostructures of scaffolds to guide cell behavior will be addressed.

\section{Preparation and properties of AuNPs}

\subsection{Synthesis routes}

The synthesis routes of AuNPs have been widely developed in order to control their shape and size, thus leading to diverse properties and multimodal applications. To date, numerous methods have been reported for preparing a wide variety of shapes (Fig. 2) such as nanospheres [21,22], nanorods [23,24], nanoplates [25], nanodumbells [26], nanostars [27,28] and nanocages [29]. Wet-chemical synthesis of AuNPs is the most common method and is carried out of presence of a stabilizer, which can bind to the atom exposed at the AuNPs surface. This capping agent allows stabilization and prevents uncontrolled growth and aggregation of the NPs. For more details regarding the processes to control AuNPs synthesis, we highly encourage to read the following reviews [30,31]. Here, we will briefly describe the «classical» methods to prepare spherical AuNPs. Typically, the AuNPs synthesis approach implies both the use of a reducing agent that serves to reduce $\mathrm{Au}^{3+}$ to $\mathrm{Au}$ atoms and a stabilizer (capping agent) to maintain colloidal stability. The synthesis of spherical NPs have been developed by Turkevish [32] in 1951 and since has been employed in a multitude of studies. NPs with a size of $20 \mathrm{~nm}$ were prepared with citric acid that acts both as the reducing and stabilizing agents. Later [33], the size-controlled NPs were developed by varying the ratio gold salt and sodium citrate. On the other hand, the preparation of anisotropic NPs such gold nanorods (AuNRs) requires the use of a template, mostly surfactant, and the most established and efficient process to prepare high yield is based on the seedgrowth method [34,35]. Firstly, gold seed are prepared by reduction of chloroauric acid salt $\left(\mathrm{HAuCl}_{4}\right)$ solution by sodium borohydride in a

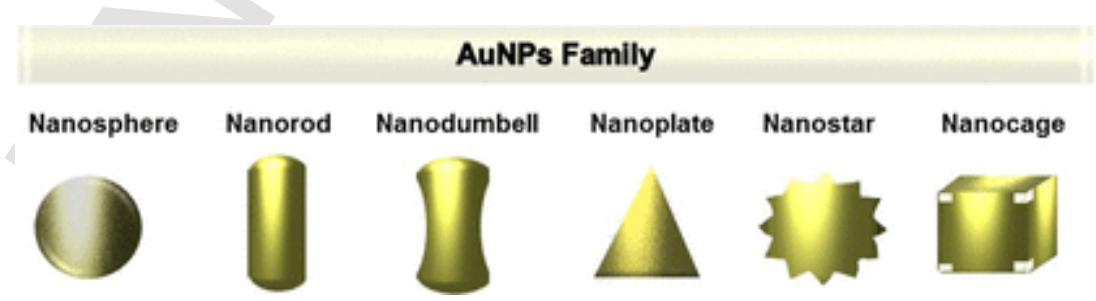

Fig. 2. Scheme representing diverse AuNPs shape. 
cetyltrimethyl ammonium bromide (CTAB) aqueous solution. Subsequently, the seed is added to a gold "growth" solution in presence of $\mathrm{CTAB}$, silver nitrate and ascorbic acid (weak reducing agent).

As aforementioned, the synthesis of AuNPs implies the reduction of gold ions and the use of a charged chemical that maintains the colloidal stability of the NPs via repulsive force. However, AuNPs exhibit low stability and biocompatibility in biological environment. Therefore, the concept of "green synthesis", using biocompatible compounds, has been considered as an alternative to conventional methods for preparing AuNPs. Taking into account that some sugars are able to reduce metal ions [36,37], polysaccharides, biomaterials with favorable properties for tissue engineering scaffolding [38-40] have also been used for the preparation of stabilized and controlled-size NPs [41]. Polysaccharides are natural polymers composed of multiple saccharides and are extracted from renewable resources such as plants, animals and microorganisms, making them environmental friendly to be used in chemistry. Moreover, they can be negatively-charged such as gum arabic, gellan gum and hyaluronic acid or positively charged as chitosan, leading to the stabilization of AuNPs in aqueous solution. On this purpose, chitosan (Cht) [42-44], gum arabic (GA) [45,46], gellan gum (GG) [47,48], guar gum [49], xanthan gum (XG) [50], and gum karaya [51] have been employed to induce the formation of highly stable and biocompatible spherical AuNPs. As an example, $\mathrm{Wu}$ et al. have developed a facile method to prepare $21.1 \pm 4.6 \mathrm{~nm}$ spherical AuNPs with fcc structure in $4 \mathrm{~h}$ at $55^{\circ} \mathrm{C}$ of reaction using GA [45]. The authors observed that by means of increasing the temperature from 25 to $75^{\circ} \mathrm{C}$ the formation rate can be modulated but it does not affect the optical properties and size of the as-prepared NPs. However, the $\mathrm{GA} / \mathrm{Au}^{3+}$ ratio has revealed to be a determinant parameter to obtain uniform particles with good stability in salt conditions. In another study, AuNPs were prepared with GG at high temperature $[48,47]$. The GG-coated NPs functionalized with sophorolipids have shown to be highly stable in a wide range of $\mathrm{pH}$ and ionic strength and no cytotoxic, making them great candidate as drug delivery carrier. In general, this approach led to the formation of spherical NPs. However, the formation of other types of shape has been reported [43,52]. Potora et al. have observed that reducing $\mathrm{HAuCl}_{4}$ with high molecular weight chitosan flakes at $100^{\circ} \mathrm{C}$ generated the formation of $18 \mathrm{~nm}$ AuNPs self-assembled in branched chains. Whereas, $27 \mathrm{~nm}$ single spherical AuNPs and gold nanoplates with lateral size from 40 to $200 \mathrm{~nm}$ were prepared at $50{ }^{\circ} \mathrm{C}$ and at $10^{\circ} \mathrm{C}$, respectively [43]. The authors hypothesized that low temperature decreases the number of seed during the nucleation step and that the amino group of Cht may interact preferentially with some facets of AuNPs, yielding a small number of NPs of large size and anisotropic shape. The Table 1 sums up the shape and size of AuNPs during the reduction of $\mathrm{HAuCl}_{4}$ at elevated temperature by diverse polysaccharides and their potential applications. It can be noticed that other materials studied suitable for tissue engineering have also demonstrated the ability to prepare AuNPs in one-step synthesis as reducer/stabilizer such as silk fibroin [53], gelatin [54,55], as well as a stabilizer such as collagen [56,57].

\subsection{Surface engineering of $A u N P s$}

Surface modification of the AuNPs is almost ineluctable to make them suitable for bio-applications [58]. Several strategies of coating have been considering taking into account the initial surface chemistry of the particles, their final application with the common objectives to make them biocompatible, stable in physiological media, but as well enable them to carry active molecules for drug delivery, diagnosis, imaging and therapy purposes. In addition, the surface modifi-
Table 1.

«Green synthesis» of AuNPs using polysaccharides.

\begin{tabular}{|c|c|c|c|c|}
\hline Polysaccharide & $\begin{array}{l}\text { Temperature } \\
\text { of synthesis }\end{array}$ & $\begin{array}{l}\text { AuNPs } \\
\text { characteristics }\end{array}$ & Studies & Ref. \\
\hline Chitosan & $\begin{array}{l}55^{\circ} \mathrm{C} \text { for } \\
2 \mathrm{~h}\end{array}$ & $\begin{array}{l}\text { Shape: spherical } \\
\text { Mean size: } 13 \mathrm{~nm}\end{array}$ & N/A & {$[41]$} \\
\hline Chitosan & $\begin{array}{l}\text { Heating for } \\
15 \mathrm{~min}\end{array}$ & $\begin{array}{l}\text { Shape: spherical } \\
\text { Mean size: } \\
20-30 \mathrm{~nm}\end{array}$ & Drug delivery & {$[42]$} \\
\hline $\begin{array}{l}\text { Chitosan flakes } \\
\text { (high } \\
\text { molecular } \\
\text { weight) }\end{array}$ & $\begin{array}{l}10{ }^{\circ} \mathrm{C} \\
50^{\circ} \mathrm{C} \\
100^{\circ} \mathrm{C}\end{array}$ & $\begin{array}{l}\text { Gold nanoplates } \\
\text { with lateral size } \\
\text { from } 40 \text { to } 200 \mathrm{~nm} \\
27 \mathrm{~nm} \text { single } \\
\text { spherical AuNPs } \\
18 \mathrm{~nm} \text { AuNPs self- } \\
\text { assembled in } \\
\text { branched chains }\end{array}$ & $\begin{array}{c}\text { Signal amplifier of } \\
\text { Surface-enhanced } \\
\text { Raman scattering }\end{array}$ & [43] \\
\hline $\begin{array}{l}\text { Low molecular } \\
\text { chitosan } \\
\text { oligosaccharide }\end{array}$ & $\begin{array}{l}25^{\circ} \mathrm{C} \\
\text { at } \mathrm{pH}: 2.9\end{array}$ & $\begin{array}{l}\text { Shape: spherical } \\
\text { Average size: } \\
115.21 \pm 16.87 \mathrm{~nm}\end{array}$ & $\begin{array}{l}\text { In vitro cytotoxicity } \\
\text { on Human } \\
\text { fibroblasts cells } \\
\text { Dose-dependent } \\
\text { effect. Cytotoxic at } \\
\text { a concentration of } \\
62.5 \mu \mathrm{g} / \mathrm{ml}\end{array}$ & [44] \\
\hline Gum Arabic & $\begin{array}{l}25^{\circ} \mathrm{C} \\
40^{\circ} \mathrm{C} \\
55^{\circ} \mathrm{C} \\
75^{\circ} \mathrm{C} \\
\text { For } 4 \mathrm{~h}\end{array}$ & $\begin{array}{l}\text { Shape: spherical } \\
\text { Mean size: } \\
21.1 \pm 4.6 \mathrm{~nm} \\
\text { Increasing the } \\
\text { reaction } \mathrm{T}^{\circ} \mathrm{C} \\
\text { increased the } \\
\text { formation rate }\end{array}$ & N/A & [45] \\
\hline Gum Arabic & Reflux & $\begin{array}{l}\text { Shape: spherical } \\
\text { Average size: } \\
15-20 \mathrm{~nm}\end{array}$ & $\begin{array}{l}\text { X-ray computing } \\
\text { tomography contrast } \\
\text { agent }\end{array}$ & [46] \\
\hline Gellan Gum & High $\mathrm{T}^{\circ} \mathrm{C}$ & $\begin{array}{l}\text { Shape: spherical } \\
\text { Mean size: } 14 \mathrm{~nm}\end{array}$ & $\begin{array}{l}\text { Cellular uptake } \\
\text { Subacute oral } \\
\text { cytotoxicity } \\
\text { Drug delivery }\end{array}$ & $\begin{array}{c}{[47]} \\
{[48]}\end{array}$ \\
\hline Guar Gum & $\begin{array}{r}80^{\circ} \mathrm{C} \text { for } \\
160 \mathrm{~min}\end{array}$ & $\begin{array}{l}\text { Shape: spherical } \\
\text { Mean size: } 6.5 \mathrm{~nm}\end{array}$ & Ammonia sensor & [49] \\
\hline Xanthan Gum & $\begin{array}{l}80^{\circ} \mathrm{C} \text { for } \\
3 \mathrm{~h}\end{array}$ & $\begin{array}{l}\text { Shape: spherical } \\
\text { Average size: } \\
15-20 \mathrm{~nm}\end{array}$ & Drug delivery & [50] \\
\hline Gum Karaya & $\begin{array}{l}90{ }^{\circ} \mathrm{C} \text { for } 1 \\
\text { hour }\end{array}$ & $\begin{array}{l}\text { Shape: spherical } \\
\text { Average size: } \\
20-25 \mathrm{~nm}\end{array}$ & Drug delivery & [51] \\
\hline
\end{tabular}

cation has been considered to minimize non-specific binding to biological components, by means of escaping to the clearance by the reticulo-endothelial system (RES) and enhancing the circulating time in order the enhance their accumulation in organ/tissue (e.g. tumor). Among those strategies, ligand exchange, encapsulation, non-bonding approach are the most common approaches (Fig. 3).

\subsubsection{Ligand exchange}

Due to the high affinity with thiol providing a strong $\mathrm{S}-\mathrm{Au}$ bond, AuNPs are coherently functionalized on their surface with compounds containing sulfur group. Typically, the modification occurs when a large excess of thiolated compounds is used, thus allowing ligand exchange. Various compounds have been anchored to AuNPs depending on the final applications [58,59]. Biological moieties such peptides, proteins, antibodies, oligonucleotides are used as probes for specific recognition of target or as therapeutic molecules, whereas polymeric compounds such as polyethylene glycol (PEG) are used to increase the circulating life and prevent non-specific adsorption. For example, oligonucleotides-anchored AuNPs have been prepared by addition of single-strand (ss)-thiolated-DNA to the NPs solution for few hours [60]. This process led to successfully cover the AuNPs surface with high number of DNA, making them very attractive for gene therapy [61] and diagnosis (Fig. 3A.1) [17]. On the 
(A) Thiol-Gold Affinity

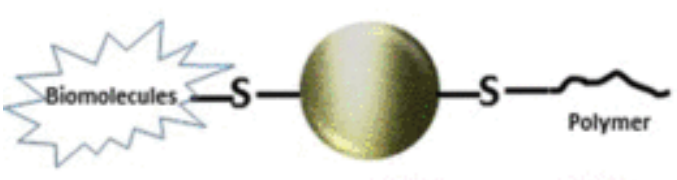

1)

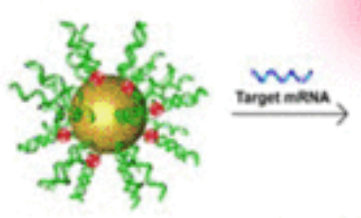

cystepenter flare rimes

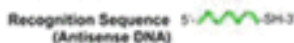

2)<smiles>CC(C)C(=O)OCCCSCCO</smiles><smiles>CC(C)C(=O)OCCOCCOC(=O)C(C)C</smiles>

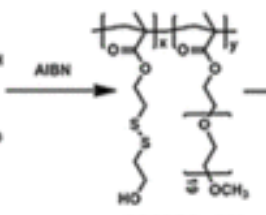

Pospegmaso

3. $x: y-1: 1 ; 4, x ; y-12$
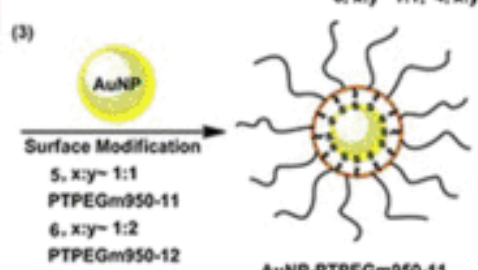

AUNP-PTPEGM9SO-11
SH:PEG $-1: 1$
Mose, 1
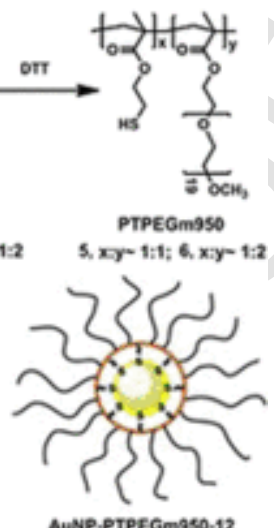

AUNP.PTPEGm950-12
SH:PEG $-1: 2$

(B) Core-shell structure
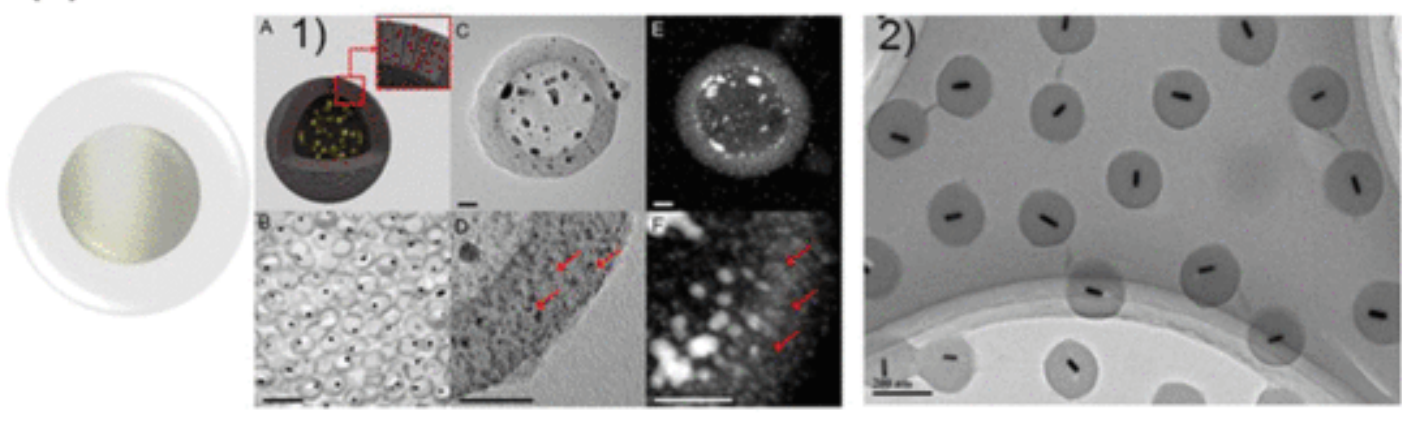

(C) Layer-by-Layer

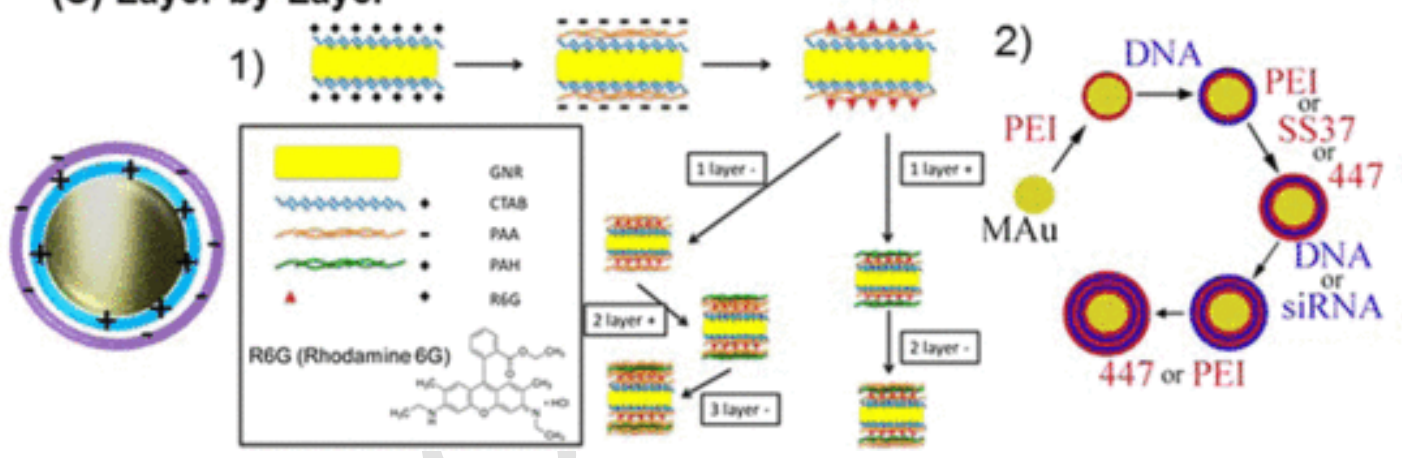

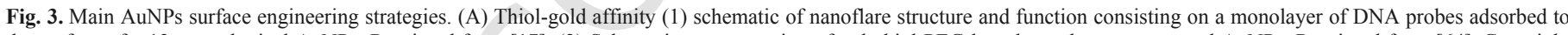

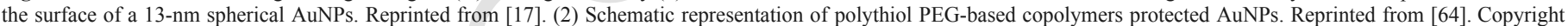

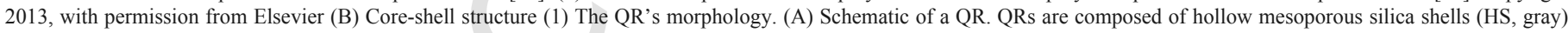

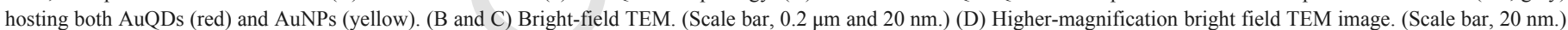

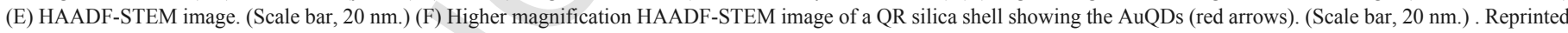

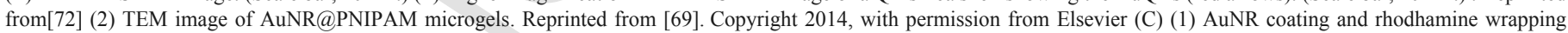

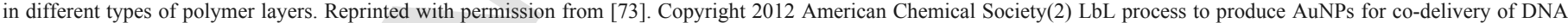

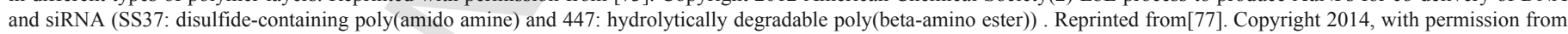
Elsevier (For interpretation of the references to colour in this figure legend, the reader is referred to the web version of this article.)

other hand, functionalization of AuNPs with thiolated-PEG has been widely investigated to minimize non-specific binding and to increase long circulating time in the RES [62,63]. Lui et al. have reported the functionalization of AuNPs with a thiol-based multidatente PEG via free radical polymerization (Fig. 3A.2) [64]. The synthesized NPs exhibited good biocompatibility and have shown better colloidal stability as compared to AuNPs anchored with mono-thiol PEG. Moreover, after in vivo assays, they observed that organs biodistribution can be tuned by playing with the PEG ligands content. Whereas higher PEG content induced a lower accumulation of the NPs in the liver, longer retention in the blood and higher uptake in the tumors, the AuNPs coated by ligands with relatively lower PEG fraction had shown lower accumulation in the spleen. 


\subsubsection{Encapsulation}

Encapsulation, also defined as a core-shell structure, implies embedding AuNPs within an inorganic or polymeric shell [65]. Additionally, the shell may exhibit functional group, allowing further modification with active molecules. That method is widely used to develop NPs-based drug delivery system, increasing greatly the drug payload and involves a multitude of possibilities with the AuNPs as core and materials such as silica [66], silver [67], polyalinine [68], poly(N-isopropylacrylamide) [69], chitosan [70], as shell. This approach leads as well to the preparation of highly monodisperse and homogeneous morphological structure and chemical composition. Silica shell around spherical, rods-like NPs have been prepared since this inorganic materials exhibit good biocompatibility and biodegradability and higher cell uptake [71]. Recently, M. Stevens'group has reported the encapsulation of $2 \mathrm{~nm}$ gold quantum dots and NPs $(>2 \mathrm{~nm})$ inside a protective and stabilizing hallow mesoporous silica shell as shown in Fig. 3B.1 [72]. In their design, gold-silica rattle (quantum rattle (QR)) allowed to stabilize gold quantum dots in the biological environment, while maintaining their photonic activity and paramagnetism. Such hybrid materials have shown interesting properties as platform for multimodal imaging and therapy. In another work, chitosan, a biomaterial widely studied in tissue engineering scaffolding has received a great interest to coat NPs, due as well to its hydrogel properties. Guo et al. have developed a multifunctional drug nanocarrier based on chitosan-modified AuNRs for real-time cell imaging, and near-NIR thermotherapy [70]. AuNRs were encapsulated within chitosan (Cht) matrix via a non-solvent-aided counterion complexation method. The Cht was then cross-linked with glutaraldehyde and the final Cht-AuNR nanosphere has found to have good biocompatibility and stability.

Another interesting approach is the use of smart polymers, i.e. polymers exhibiting reversible response features toward the use of external stimuli such temperature and $\mathrm{pH}$. Poly( $\mathrm{N}$-isopropylacrylamide) (PNIPAM), for example, undergoes a volume phase transition around $32{ }^{\circ} \mathrm{C}$. At room temperature, PNIPAM exhibits a random coil conformation in aqueous solution, whereas at temperature above $32{ }^{\circ} \mathrm{C}$ it separates from the solution. PNIPAM has been embedded around particles to prepare thermo-responsive nanomaterials for diagnosis. Coreshell structure of gold nanorods covered by a cross-linked PNIPAM microgels [69] have been prepared by seed-precipitation polymerization method using butenoic acid modified AuNRs as seeds (Fig. 3B.2). Tuning the temperature from 20 to $48^{\circ} \mathrm{C}$, and vice-versa, has provoked a reversible shift of the LPB from 745 to $804 \mathrm{~nm}$, leading to the development of a monodisperse thermo-responsive plasmonic nanostructure.

\subsubsection{Non-covalent surface modification}

Non-covalent surface modification of NPs has been widely exploited and it is mainly based on electrostatic interactions. The Layerby-Layer (LBL) method consists on the alternative deposition of anionic and cationic polyelectrolytes on the NPs surface, resulting to the formation of onion-like multilayers structure, where charged target molecules can also been incorporated. On this purpose, a multiple strategy has been developed using charged compounds such as polyelectrolytes [73-75], oligonucleotides [76-78], proteins [79], antibodies [80]. Multilayer of poly-acrylic acid/poly-allylamine has been used to entrapped rhodamine to develop a model for drug photorelease (Fig. 3C.1) [73]. Recently, Bishop et al. have developed a proof-of-concept multi-layer AuNPs to co-release DNA and SiRNA through LBL biodegradable polymers coating strategy (Fig. 3C.2) [77]. Different types of polymers have been studied such as poly(eth- ylenimine) (PEI), poly(amido amine) (SS37) and poly(beta amido ester) (447). In their design, AuNPs were alternatively coated with PEI/ DNA/PEI or SS37 or 447/DNA or siRNA/PEI or 447. The reported NPs led to exogeneous DNA expression and siRNA-mediated knockdown. Likewise, a polystyrene sulfonate/polyallylamine bilayer has been deposited around AuNRs to develop a biocompatible nanocarrier that can be loaded and deliver small interfering RNA (siRNA) against LDS1 in order to induce differentiation of human mesenchymal stem cells [81].

\subsection{Cytotoxicity and cells-AuNPs interactions}

One of the requirements to fulfill the objectives of TERM is to use a non-toxic system for cells, i.e., a bioinert or biodegradable system. Cytotoxicity studies of AuNPs need to be carefully assessed for their use in biomedicine [82]. Therefore, in vitro assays and in vivo animal models to determine biocompatibility of AuNPs have been considered before further use in human. While it is stipulated that gold core is inert, the literature remained still unclear and unreliable on the effect of AuNPs within cells. Typically, cytotoxicity may be related to the size $[83,84]$, concentration [85], and surface chemical composition [86,87], and the cell type [88]. Naha and colleagues have studied the cytotoxicity of a library of NPs with different shapes (spheres and rods), surface coatings (e.g. citrate, silicate, lipoprotein, polymaleic acid, polyethylene glycol and DNA) and sizes (in a range from 3 to $145 \mathrm{~nm}$ ) [86]. The particles were cultured in three types of mammalian cells lines, namely human fibroblasts (BJ5ta9), human colon epithelial $(\mathrm{C} 2 \mathrm{BBe} 1)$ and mouse macrophages. Based on the MTS assay and cell cytoskeleton analysis, it was reported that after $1 \mathrm{~h}$ of cell exposure, none of NPs exhibited a significant decrease of cell viability, whereas after $24 \mathrm{~h}$, it was observed that AuNRs and DNA-coated AuNPs can induce cytotoxicity. In their research, they concluded that surface agent was the leading cause of cytotoxicity over the cellular uptake capacity.

AuNPs-mediated cytotoxicity is usually dose-dependent and associated to membrane damage, cell contents leakage and reactive oxygen species (ROS) generation. For example, high level of ROS may induce DNA damage or affect mitochondrial viability, leading to cell apoptosis $[89,90]$. Un-modified and commercially AuNRs $(52 \mathrm{~nm} \times 25 \mathrm{~nm})$ have been cultured for $4 \mathrm{~h}$ in A549 cells, a human lung adenocarcinoma cell line with a range of concentration between 2.5 and $15 \mu \mathrm{g} / \mathrm{mL}$ [91]. Upon NPs internalization, the cell membrane was damaged, resulting in lactase dehydrogenase (LDH) leak. In addition, the high levels of ROS production have been identified as the main cause of cytotoxicity. However, in oncology in which cancer cell death is intentionally induced, damaging cell cytoskeleton could be a good strategy. Targeting mitochondria with AuNPs led to disrupt the mitochondrial membrane. The intermembrane cytochrome c was released to the cytosol, which activated the caspase signaling pathway and generated breast cancer apoptosis [92].

In order to obtain more consensual outcomes, few reports focused on providing standardized in vitro protocols [84,85]. Recently, Soenen et al. have described a multiparameter strategy to evaluate the cytotoxicity of $14 \mathrm{~nm}$ poly(methacrylic acid)-coated AuNPs with $4 \mathrm{~nm}$ $\mathrm{Au}$ core [85]. NPs at 10, 20, 50, 100, 200 and $500 \mathrm{nM}$ have been incubated for 4 and $24 \mathrm{~h}$ with three different cell lines: C17.2 neural progenitor cells, primary HUVECs and rat PC12 cells. To better understand the effect of the NPs on the cells behavior, different but complementary in vitro assays such as cell viability, ROS, cell morphology, cytoskeleton architecture and cell functionality have been assessed. All together, the assays have shown that the two highest concentrations induced cell apoptosis, mostly through the production 
of ROS. However, even though no decrease of cell viability was detected at lower concentrations, the best condition was $10 \mathrm{nM}$. Only at this concentration, all cell functions were preserved. That study highlighted the importance of merging diverse assays to insure good cellNPs interaction.

To prevent those deleterious health effects in which surface chemistry has been identified as a dominant factor, a great effort have emerged to prepare AuNPs through green synthesis strategy. Most of the reports have claimed a good biocompatibility of the NPs. Xanthan gum-stabilized AuNPs have shown to be no cytotoxic to A549 human lung cancer cells for $48 \mathrm{~h}$ [50], whereas Cht-AuNPs have shown a dose-dependent cytotoxicity against human fibroblasts cells, resulting from a cell viability decrease at concentrations higher than $62.5 \mu \mathrm{g} /$ $\mathrm{mL}$ [44].

\section{AuNPs for multimodal applications}

The development and the use of multimodal NPs able to act at the same time as therapeutic, diagnostic and imaging agents are the cutting-edge research in which TERM may benefit. We can cite the recent successful development of gold-silica quantum rattles (Fig. 3B1) that hold a variety of functionalities including drug delivery, photothermal therapy in combination with three imaging modalities such as NIR fluorescence, photoacoutic and magnetic resonance imaging [72]. In this context, AuNPs can be seen as a potential nanotool (Fig. 4) for multimodal applications since they enable: (i) to deliver biological and chemical active molecules in a spatial and temporal-manner to improve therapeutic outcomes, (ii) to diagnose cells proliferation and differentiation, and (iii) to label cells and tracking of implanted cells.

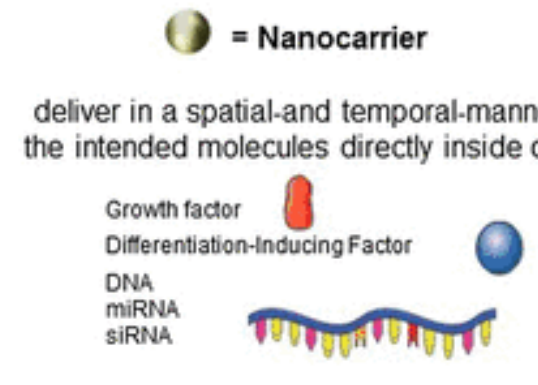

$\Theta=$ Nanoprobe

Diagnose

undifferentiated vs differentiated stem cells (2)

$\Theta=$ Contrast agent Enhance in vivo cell tracking image contrast
- Photoacoustic imaging

- two-photon luminescence imaging

- optical coherence tomography

- X-ray computed tomography

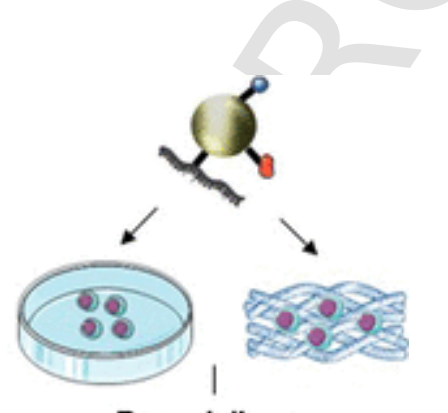

Drug delivery

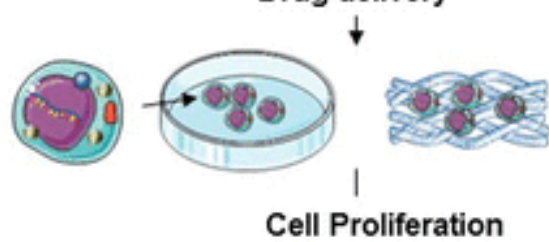

$\downarrow$

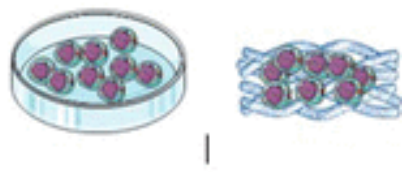

Cell Differentiation
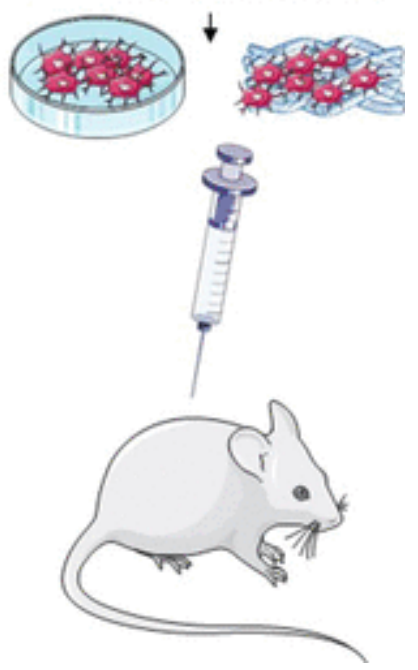

Fig. 4. Scheme representing the use of AuNPs to control and track cell behavior as a drug nanocarrier, as a nanoprobe and finally as a contrast agent for implanted cells. 


\subsection{AuNPs-based therapy}

\subsubsection{AuNPs-based drug delivery system}

The controlled delivery of active biomolecules in live cells or organic tissues to improve therapeutic outcomes is one of major research area in biomedicine. However, the intracellular release of such compounds in the area of lesion remains an important challenge, especially due to the lack of physiological solubility of the molecules and a low cell membrane permeability. Thereby, high-doses are usually administrated, likely involving undesired side effects. The rationale behind the loading of bioactive molecules in nanomaterials or attached to their surface is a breakthrough that allowed delivering in a spatial-and temporal-manner the intended molecules directly inside cells $[93,94]$. AuNPs have gained attention as drug delivery system (DDS) since they exhibit high-density surface allowing high yield ligand anchorage, facile transmembrane delivery, targeting cellular delivery and controlled intracellular release. In cancer therapy, AuNPsbased vehicles allow to enhance the in vitro and in vivo therapeutic activity of diverse chemotherapies such as temozolomide [95] on malignant glioma-derived cancer stem cell, doxorubicin (Dox) on human glioma cell [96], breast cancer stem cells [15], human melanoma cell line [97]; and to promote crossing the blood barrier, thereby facilitating greater accumulation of the drug in tumor cells [96].

In TERM field, the strategy of using NPs aims to administrate biological factors [98], drugs [99] and genetic materials [100] to the implanted cells inside a 3D scaffold in order to mimic the extracellular matrix and enhance tissue regeneration [101]. In order to treat bone-related diseases, AuNPs have also been conjugated with bisphosphonate for osteonecrosis [102] and with glycating agents (e.g. fructose and bovine serum albumin) to inhibit the growth of bone cancer cell [103]. PEGylated AuNPs conjugated with a fragment of neural cell adhesion molecule L1 led to enhance the intracellular delivery of the biomolecules. They also stimulated L1-mediated functions in murine primary neurons and Schwann cells. The bioconjugates are thus a promising tool for neuron regeneration after nervous system injury [104]. Likewise, PEGylayted AuNPs have been reported to be a favorable drug delivery platform with therapeutic potential. Papstefanaki et al. have administered PEG-AuNPs via intraspinal injection in mouse model after spinal cord injury, which led to promote hind limb motor recovery in addition with a decrease of inflammatory response, enhancement of motor neural survival and increase remyelination [105].

Compared to direct adsorption of the bioactive molecule on the surface of an implanted scaffold, a carrier delivery system provides controlled, long-term release with adequate efficacy [99]. Kumari et al. have reported that the incorporation of the flower-like AuNPs in glycolic acid grafted chitosan scaffolds allowed the control of drug release of cysclophosphamide [106]. Contrary to the fast release of the drug at the surface of the crude scaffold, the presence of the $\mathrm{Au}$ nanoflower allowed decreasing the release rate of the carried drug. Later on, they synthetized a hybrid scaffold composed of chitosan-gglycolic acid and $\mathrm{Au}-\mathrm{Fe}_{3} \mathrm{O}_{4} \mathrm{NPs}$ [107]. The composite have shown to be more resistant to $\mathrm{pH}$ and to have a role in cell adhesion, proliferation and migration. Moreover, the presence of $\mathrm{Au}-\mathrm{Fe}_{3} \mathrm{O}_{4}$ allowed the decrease of drug release rate in PBS ( $\mathrm{pH} 7.4)$.

The capacity of switch on/off the release of the drugs from environmental changes such as temperature, $\mathrm{pH}$, light, and mechanical stress directly to the cell is very attractive, in term of controlling the rate and the dose of the released drug [108]. Recently, Kearney et al. have reported a proof-of-principle for on-demand delivery of bone morphogenetic protein-2 (BMP-2)-AuNPs into 3D microbeads alginate scaffold using ultrasound [109]. Upon ultrasonic stimulation, BMP-2 was released from AuNPs. The resulting supernatant was administered to mMSCs, which led to twofold increase in alkaline phosphatase activity over osteogenic media controls. The authors claimed that this approach can be regarded as an alternative to release in a precise fashion growth factor inside scaffolds.

Gene therapy, e.g. delivering biological molecules such as DNA and siRNA to regulate cells behavior holds great promise for TERM, but may be limited to intracellular entry of the oligonucleotides. AuNPs have been used for gene delivery to enhance transfection efficiency, cell proliferation and differentiation [61]. Tencomnao et al. have prepared gold/Cht/PEI nanoscaffolds as non-viral gene carrier, on which Luciferase-encoding plasmid DNA were adsorbed [78]. The resulting nanocomplex has shown higher transfection efficiency on a human lung adenocarcinoma epithelial cell line (A549) and a human cervical cancer cell line (HeLa) than polymeric-based carriers and can be used as an alternative to viral gene delivery system.

Interestingly, the successful delivery of siRNA via AuNRs has provoked the down-regulation of lysine-specific demethylase 1 (LSD1) inducing the differentiation of human mesenchymal stem cells (hMSCs) [81]. Then, supplemented with hepatocyte growth factor, the nanocarrier enhanced the differentiation of hMSCs into a hepatocyte lineage. All these studies highlight the importance of considering AuNPs as a carrier to deliver siRNA, DNA for tissue regeneration treatment.

Another factor to be addressed is the interaction with complex tissues (e.g. skin), which extend at larger scales than the cells. Fernandes et al. have investigated the effect of the penetration of AuNPs through human and mouse skin depending on the morphology, charge and function of the NPs [110]. They observed that positively charged and rod-shape of AuNPs are favorable for the penetration of skin. When functionalized with cell penetrating peptide, they are found in the deeper layer of the skin. AuNPs hold promise as drug-delivery systems because of their ability to penetrate and interact with the skin.

\subsubsection{AuNPs-based photothermal therapy}

Despite the great achievement exploiting AuNPs-mediated photothermal therapy (PT) in cancer research, this concept is still at its infancy in the field of TERM. However, we will discuss about this concept and the new trends combining PT with others modalities since we assume that in the near future PT-based tissue engineering strategies will emerge. In this sense, we can mention the photorelease of PCmiR-148b from silver NPs in order to modulate the osteogenic differentiation of hASCs using light as a non-invasive triggering modality [111].

Typically, PT is a non-invasive technique consisting on the destruction of cell through heat. Upon exposure to a laser beam, AuNPs enable to absorb light and to convert it into heat with high efficacy and thus this technique has been employed to locally destroy cancer cells [112,113]. Various shapes of AuNPs such nanospheres [114], nanorods [115], nanocages [116,117], nanoshells [118], and caged gold nanorods [119] have been served on this purpose [120]. However, gold nanostructures with optical properties tunable in the nearinfrared region (650-900 $\mathrm{nm}$ ) are particularly attractive for cancer therapy. This optical window is considered to be the best spectral region, due the relatively low attenuation of blood and soft tissue allowing deep penetration. On particularly, AuNRs have shown to be very effective in eliminating malignant cancer cells related to brain [115], breast [121,122], liver [123], and therefore represent an important area of research for therapeutic development. Cabada et al. have 
reported a significant decrease of cell viability of glioblastoma after $20 \mathrm{~min}$ of laser irradiation in the presence of AuNRs, while no decrease in cell viability was observed with laser irradiation or incubation with AuNRs alone [115]. Likewise, Huang et al. have photo-thermally and selectively killed two malignant cells, leaving the healthy cells unaffected [124].

However, new therapeutic strategies are still under investigation in order to achieve more efficient outcomes. Combining different therapy modalities in a unique system, instead of using them individually, will allow enhancing their efficacy and reduce their side effects. Taking advantages of the ability of AuNPs to carry drugs, researchers and clinicians have envisaged that heating the surfaces of the NPs without measurably increasing the temperature of the surroundings offers as well the possibility of photo-release without killing cells. Therefore, multimodal NPs combining both chemotherapy and PT can have a significant clinical potential for the ablation of tumor both in vitro and in vivo [125]. Wang et al. designed a multi-responsive nanoplatform based on dox-loaded gold nanocages [126]. NIR light irradiation have shown to enhance the release of Dox from the NPs in cancer cells and dramatically improved the therapeutic efficiency. Both in vitro and in vivo results demonstrated that the combination of PT and chemotherapy resulted in harsh cell toxicity, while chemotherapy or PT treatment alone could not reached these effects [127]. Very recently, methotrexate, an anti-rheumatic drugs, encapsulated within poly(lactic-co-glycolic acid) PLGA NPs have been com- bined with gold NPs or gold nanoshells for chemo-phothermal treatment of rheumatoid arthritis [128,129].

To push the barrier further, AuNRs have been, recently, designed and multi-functionalized to synergistically combined chemotherapy, hyperthermia and immunotherapy [130]. Doxorubicin,an anticancer drug, and non-methylated cytosine-guanosine $(\mathrm{CpG})$ oligodeoxynucleotide $_{s}$,an immunostimulator, have both been attached to AuNRs and simultaneously delivered to tumor tissue after irradiation (Fig. $5 \mathrm{~A})$. The engineering vehicle exhibited in vitro and in vivo significant antitumor efficacy (Fig. 5B). Likewise, the doxorubicin release from hollow AuNPs after NIR laser and radiation in murine tumor xenograft model led to delay tumor growth by a factor 4.3 and reduce tumor weight by 6.8 -fold compare to control tumors [131]. The synergetic effect of cell therapy combined with PT has also been reported. Recently, AuNRs have been loaded in tumor-tropic neural stem cells (NSCs) in order to favor the removal of entire tumor mass and to prevent the collateral damage to the surrounding healthy tissue [132]. This innovative approach allowed increasing the concentration of particles throughout tumor when carried by NSCs, as evidenced by reduced recurrence rates of triple-negative breast cancer (MDA-MB-231) xenografts following NIR exposure. This method that showed improvement of efficacy AuNRs-loaded NSCs on as compared to free AuNRs may be considered as a new generation for cancer therapy.

Exploiting the PT-based cancer therapy concept, Adah Almutairi, professor at the University San Diego have developed a system for

(A)
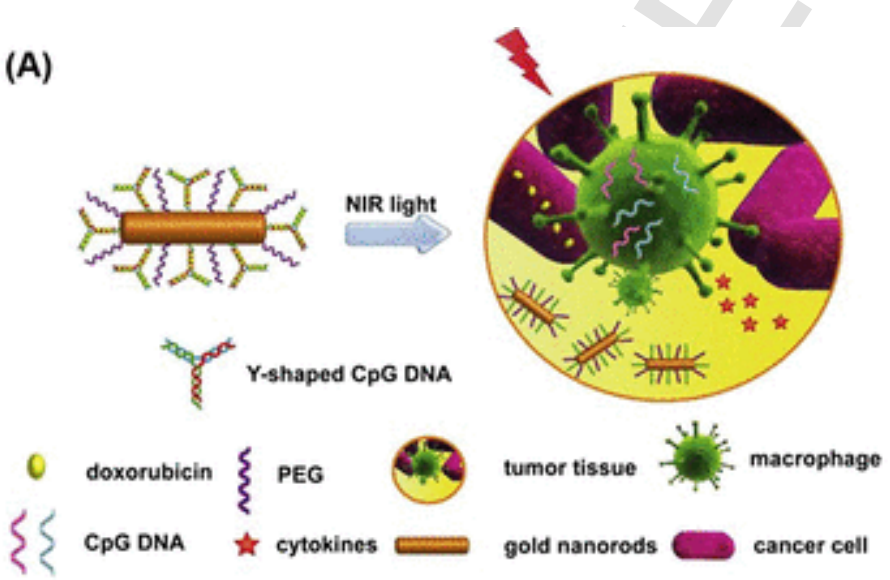

(B)
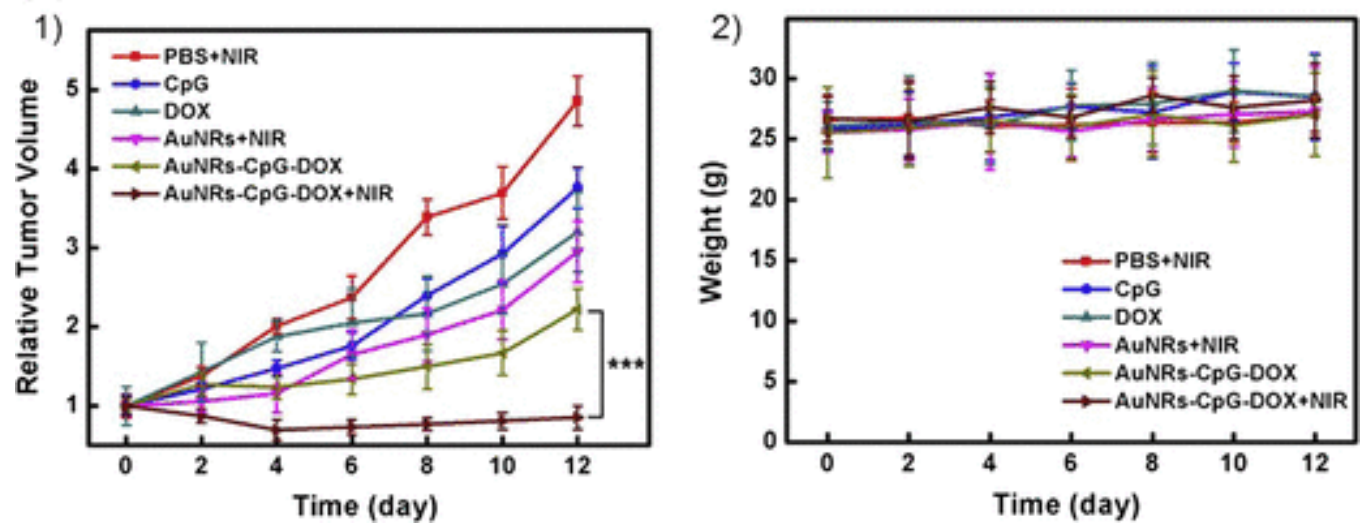

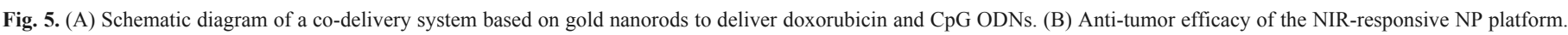

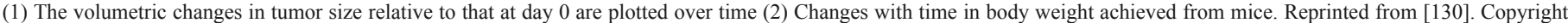
2014, with permission from Elsevier 
fat removal using NPs-based liposuction [133], called «NanoLipo». This technology relies on the selective and local heating of adipose tissue upon external near-infrared laser exposure of AuNR allowing the fat to be liquefied and easily aspirated. The study assessed in Yucatan mini pigs have demonstrated that NanoLipo facilitates removal of twice as much fat and requires less time (4 vs $10 \mathrm{~min}$ ) than conventional suction assisted-lipectomy.

\subsection{AuNPs-based stem cell labeling and tracking}

The evaluation of differentiation and pluripotency of stem cells is crucial and will help for a better understanding of how manipulate stem cells in the area of TERM. The current methods used to detect the differentiation status are based on the analysis of specific biomarkers related to the differentiated stem cells. Gene marker expression to evaluate the differentiation mechanism is detected using polymerase chain reaction (PCR). However, this cumbersome method required the use of a large amount of cells. Therefore, there is a need to diagnose differentiated $v s$ undifferentiated stem cells in an easy (fast and user-friendly protocols), non-destructive, in situ and long-term ways $[134,135]$.

Due to their interesting absorption and scattering properties, AuNPs have been widely used to detect macromolecules (e.g. proteins [136], oligonucleotides [137,138]), cancer [139] and other diseases [140], virus [141] and bacteria [142]. A variety of biosensing strategies have been considered using AuNPs either as signal amplifier[143] or as signal inducer [144]. Therefore, AuNPs may offer a multitude of probe-target recognition-induced signal approaches to distinguish stem cells in each stage of their differentiation process.

Surface-enhanced Raman spectroscopy (SERS) is a non-destructive technique used in the detection of chemical and biological compounds and that has shown promising results to determine the status of stem cells differentiation. In presence of AuNPs, the SERS signal is enhanced, leading to an improvement of the sensitivity [143,145]. Kim et al. have used this technique in combination with a 3D graphene oxide-encapsulated AuNPs (GO-Au) for the detection of the potential differentiation of neural stem cells (NSCs) [146]. The concept was based on the fact that undifferentiated stem cells exhibit polyunsaturated membranes and unsaturated molecules that are rich in $\mathrm{C}=$ $\mathrm{C}$ bonds due to aromatic structures. Undifferentiated and differentiated NSCs were analyzed using GO-Au-based SERS. The results have shown that the Raman signals when the cell were non-differentiated were more intense, enabling net discrimination between undifferentiated/differentiated state of NSCs. Kuyen li et al. have developed a multiplex approach for the detection of cell surface markers CD44 and CD24 in three breast cancer lines [147]. Their design consisted on targeting the markers through specific recognition with antibody-conjugated AuNPs (pointer). The SERS signal was enhanced upon the addition of (ss)DNA-conjugated AuNPs (enhancer), arising through hybridization-mediated pointer-enhancer aggregation.

AuNPs can act as a signal inducer due to their optical properties, which led to the development of multitude of colorimetric and immunoassays [148-150]. Distinction between different cell types including 786-O (human kidney carcinoma cell line), L929 (murine aneuploid fibrosarcoma cell line), HeLa and RAW264.7 (macrophage cell line) have occurred using enhanced nanoplasmonic effect of AuNPs [139]. Lateral flow assays using AuNPs as optical molecular probes have also been exploited as analytical method for the detection of miRNA [151], food-borne pathogens [152], heavy metals [153]. This technique based on competitive immunoassay provides a fast, easy and on-site qualitative visual responses (yes/no result) of the presence of a target analyte for a wide range of medical, food, en- vironmental applications, and it is well-known as home pregnancy test. By it turns, lateral flow immunosystems based on the double antibody sandwich methods have been developed to detect human pluripotent stem cells (hPSCs) [154]. The device allowed the detection of $1 \times 10^{4}$ cells within 20 min by the naked eyes and 7000 stem cells with a portable strip reader. The response of the optimized LFB was highly linear over a range of $1 \times 10^{4}$ to $2 \times 10^{5}$ human stem cells. Later on, the same group has developed a nucleic acid lateral flow to enhance hPSCs detection efficacy [155]. Firstly, magnetic beads coated with antibody were used to enrich the target cells and the secondary antibody linked with an oligonucleotide was used as amplification method. Then the oligonucleotide was amplified and detected with the lateral flow biosensor (Fig. 6A). That strategy allowed detecting a minimum of $100 \mathrm{hPSCs}$ within $80 \mathrm{~min}$ time by naked eye (Fig. 6B and C). The LFB can have important applications in the field of regenerative medicine such as to determine the efficiency to stem cell to differentiate in a specific lineage.

With the aim of detecting of live human mesenchymal stems cells during their differentiation process, Choi et al. have exploiting the fluorescent quenching effect of AuNPs based on the fluorescence resonance energy transfer (FRET) [156]. Typically, fluorescent probes are attached to the particles, which obstructs their fluorescence properties. Upon probe-target recognition, the fluorescent probes are released from AuNPs leading to a fluorescent signal. In their work, they reported the differentiation status of hMSCs (i.e., differentiated vs undifferentiated) via the detection of miRNAs in living stem cells (Fig. 7A). In the differentiated status, specific miRNA such as miR-29b and miR-31 are up-regulated during osteogenic differentiation. Thus, heparin DNA strands (hpDNAs) that can recognize these two osteogenic miRNAs markers, were attached to dopamine@AuNPs (Au@PDA). Upon target miRNAs, hpDNAs was dissociated from Au@PDA and recovered their fluorescence features. The Au@PDA nanoprobe was internalized inside undifferentiated and osteogenic differentiated hMSCs, and inside living primary osteoblast and 3T3 fibroblasts. Fluorescence was detected when the cells presented osteoblast profiles (Fig. 7B). More importantly, their nanoprobes provided long-term tracking of intracellular miRNAs in living stem cells, which couldnt be achieved by commercially available RNA detection probe such as SmartFlare [156].

\subsection{AuNPs-based cellular imaging}

The imaging of cells proliferation, differentiation and tissue regeneration $[157,158]$ is crucial not only to determine morphological structure and the localization of transplanted cells within the body or inside scaffold but as well to evaluate how the cells respond and interact to the microenvironment. To overcome the traditional invasive techniques (e.g. immunohistochemistry, histochemistry), the new emerging imaging techniques might have to be non-invasive, and capable of sensitive, quantitative, longitudinal assessment of cell behaviors with high spatial and temporal resolutions at sufficient depth. Nowadays, dark-field microscopy [159], magnetic resonance imaging [160,161], ultrasound imaging [162], two-photon luminescence imaging [163], photoacoustic tomography [164], optical coherence tomography (OCT) [165] and X-ray computed tomography [166] have been investigated individually or combined in nanomedicine, enabling cells tracking. Due to their scattering and light absorption properties, as well as their high photostability compared to traditional dyes or semiconductor crystals, AuNPs have been used as contrast agent in order to provide a better visualization and thus improve the performance of such techniques [157], For example, $30 \mathrm{nM}$ of AuNRs injected to the anterior chamber of mice eyes have produced a contrast 
(A)

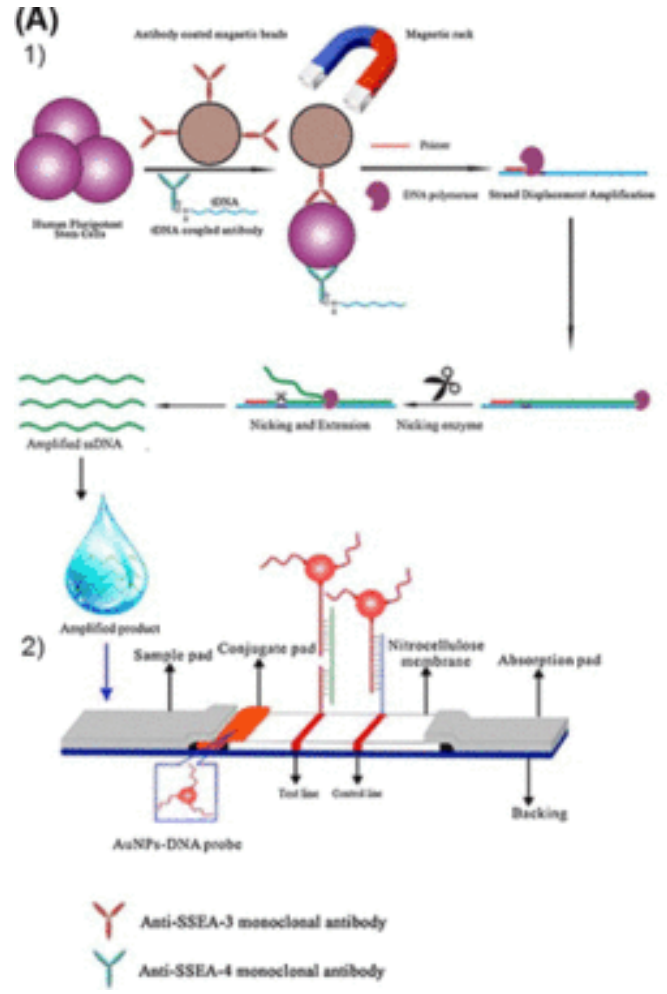

(B)
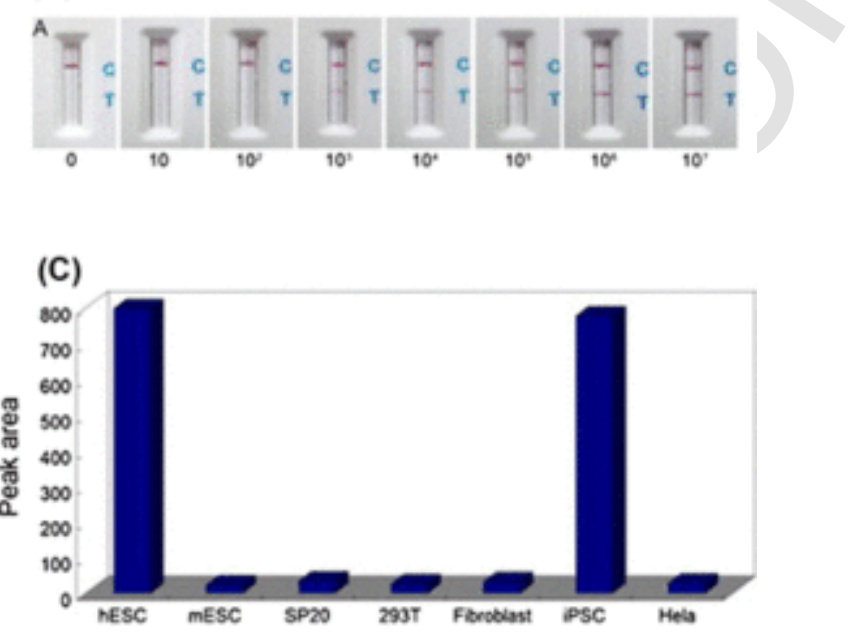

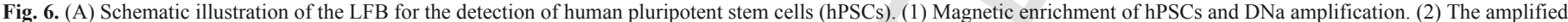

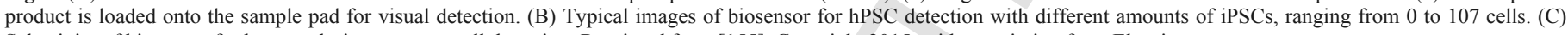
Selectivity of biosensor for human pluripotent stem cell detection. Reprinted from [155]. Copyright 2015, with permission from Elsevier

signal $50 \%$ higher than the control with saline injection, making them suitable to be used with OCT (Fig. 8A). Hence, AuNPs offer a great potential for cell labeling, thus offering the opportunity to visualize and track cell in vitro and in vivo.

Dark-field microscopy has been mainly used to evaluate cellular uptake [167,168], cell migration [169], molecular affinity [170]. This modality collects scattered light from a sample to show its scattering properties. The particles are excited by a broad white-light source, but only light frequencies matching the LSPR are strongly scattered. Thus, AuNPs are visualized as bright spots. Dark-field imaging has been also used to determine the affinity of DNA-modified AuNPs with different end group (e.g. $\mathrm{NH}_{3}, \mathrm{PO}_{3}, \mathrm{OH}, \mathrm{CH}_{3}$ and $\mathrm{SH}$ ) AuNPs to be internalized in human hepatoma HepG2. The results have shown that tuning surface functionality alters the internalization process, resulting on a lower uptake of NPs with $\mathrm{CH}_{3}$ and $\mathrm{SH}$ groups. Boca et al. have reported the high affinity of chitosan-gold NPs with Chinese hamster ovary [168].

Photoacoustic (PA) imaging is a common modality in biomedicine and is based on the detection of acoustic waves generated by thermal expansion of tissue when exposed to laser pulse. AuNPs have shown to be very promising as contrast for PA imaging due to their strong light absorption properties. For example, silica-coated AuNRs internalized in mesenchymal stem cells allowed the tracking of these cells in living mice by enhancing the PA signal [71]. Likewise, gold hallow nanospheres showed better contrast and clarity of the mouse brain vascular image, than PA imaging without contrast [171]. Gold nanocages have demonstrated to be a promising contrast agent for the tracking of human mesenchymal stem cells using two-photon and PA imaging modalities [172]. In another works, stem cells have been labeled with $20 \mathrm{~nm}$ AuNPs (nanotracers) to monitor the regenerative process of mesenchymal stem cells $[173,174]$ and adipose-derived stem cells [175] in 3D PEGylated fibrin gel for vascular and dermal tissue engineering. Combining ultrasound (US) imaging with PA imaging allowed to monitor MSCs after injection of rat muscle [174]. Firstly, AuNPs were internalized by MSCs, as confirmed by darkfield microscopy. Subsequently, the labeled MSCs were cultured in PEGylated fibrin gels and implanted at the ischemic region, followed by US-guided PA imaging (Fig. 8B). The synergistic effect of the both modalities provided information about the neovascularization and MSCs distribution. While the MSCs without AuNPs did not produce any PA signal, gold-labeled MSCs were imaged over a 1-week time period, which implies the possibility of longitudinal cell tracking using PA imaging.

X-ray computed tomography is one of the leading radiological technologies applied in the field of biomedical imaging. Cole et al. have used bisphosphonate-functionalized gold nanoparticles (BPAuNPs) as radiographic contrast agent to detect breast microcalcification in vitro and in ex vivo tissue model [176]. To mimic the heterogeneity of the breast tissue, different concentrations of hydroxyapatite in a Matrigel ${ }^{\circledR}$ carrier were injected into murine mammary glands. The X-ray attenuation of HA-Matrigel compositions labeled by BP-Au NPs was increased by up to $289 \mathrm{HU}$ compared to unlabeled compositions for HA concentrations ranging from 0.5 to $25 \mathrm{mg}$ / $\mathrm{mL}$, which included an HA concentration $(0.5 \mathrm{mg} / \mathrm{mL})$ that was otherwise undetectable by micro-computed tomography. In another study, near-infrared fluorescent silica-coated AuNPs $\left(\mathrm{Au} @ \mathrm{SiO}_{2}\right)$ in partnership with a dual fluorescent/X-ray CT modal imaging system allowed to provide anatomical information, including the location and size of lymphs nodes (LNs) and lymphs vessel LVs for deciding a surgery plan (Fig. 8C) [19]. In the axial CT images, the cervical LNs were localized and their size was determined around $2 \mathrm{~mm}$, which was in agreement with their actual size. $\mathrm{Au} @ \mathrm{SiO}_{2}$ ex- 


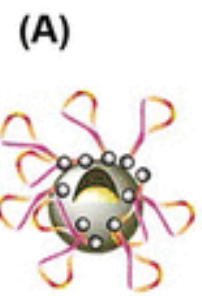

Nanoprobe

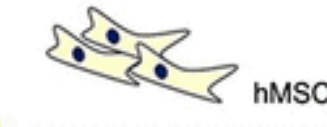

Incubation for $24 \mathrm{~h}$

(B)
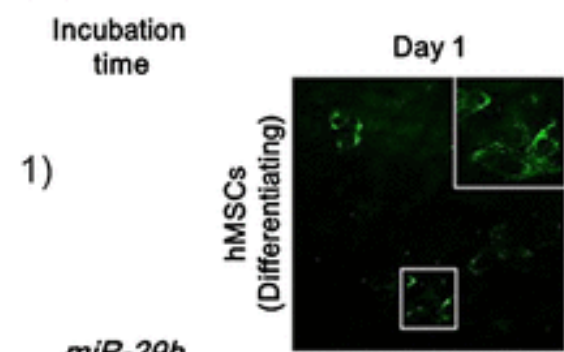

$m i R-29 b$

2)
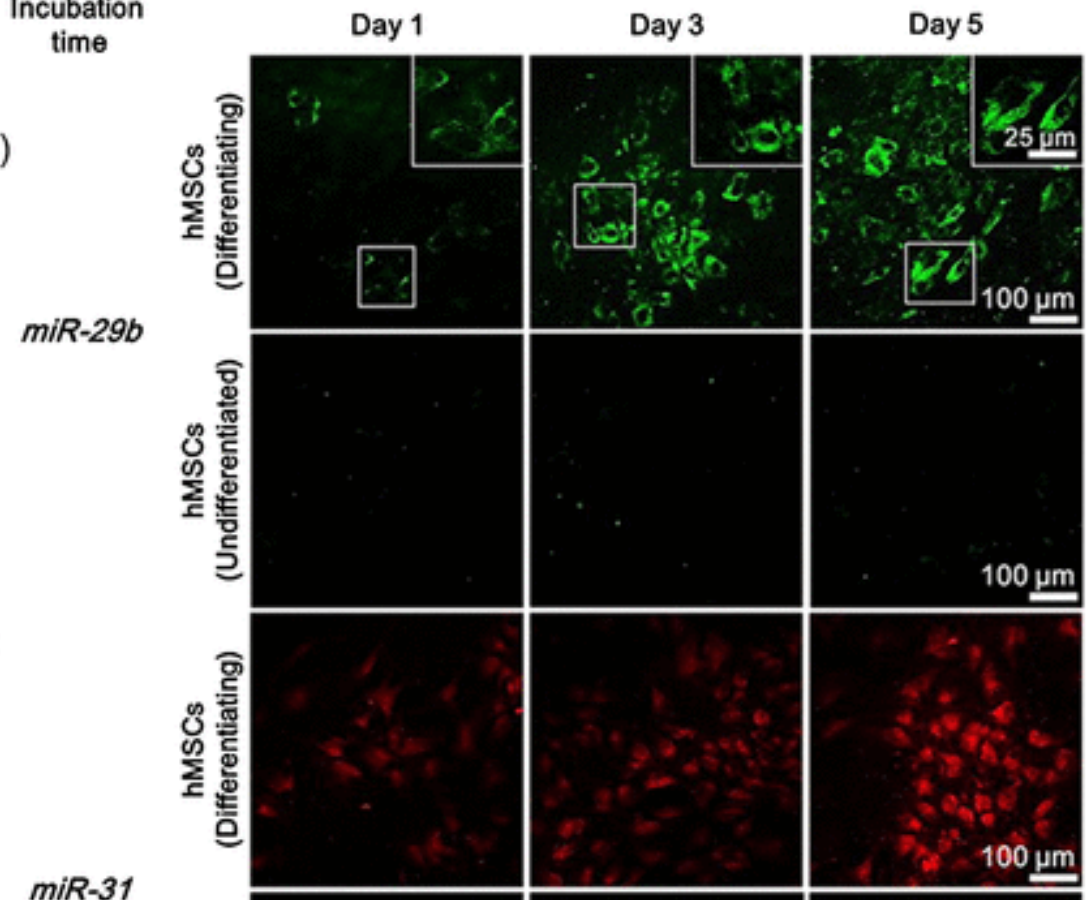

$\operatorname{miR}-31$
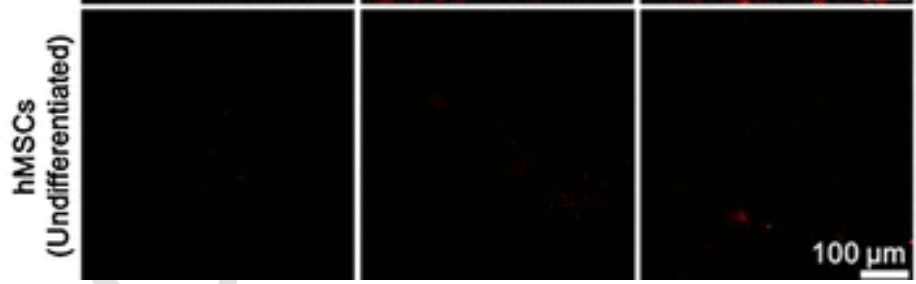

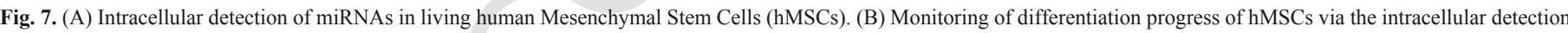

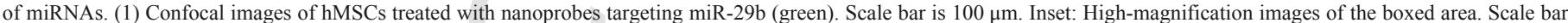

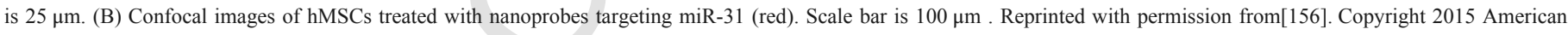
Chemical Society. (For interpretation of the references to colour in this figure legend, the reader is referred to the web version of this article.)

hibited a higher CT contrast than the Iopamiron, iodine-containing molecule used as a CT contrast agent, at similar molar concentration, which highlight then their promising use for CT.

The aforementioned techniques can profit from AuNPs, enabling the location and the size of tissue that might be interesting to be used when cells and scaffold are implanted within body to follow in realtime tissue formation.

\section{AuNPs in TERM strategies}

\subsection{AuNPs-based strategy to enhance stem cell differentiation for} bone tissue engineering

In the human system, the formation of bone tissue is induced by osteogenic differentiation of mesenchymal stem cells towards osteoblasts. Subsequently, these cells synthetize and mineralize the collagenous extracellular matrix of the bone. The strategy of bone tissue engineering aims to promote the osteogenic differentiation and min- 
(A)

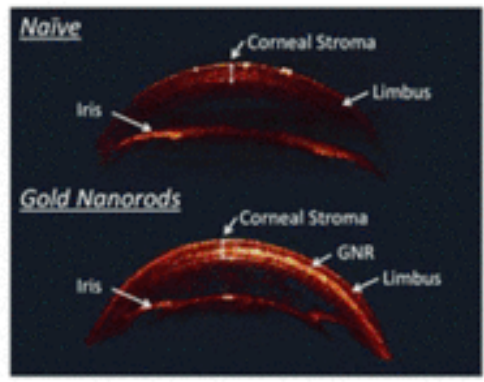

(C)

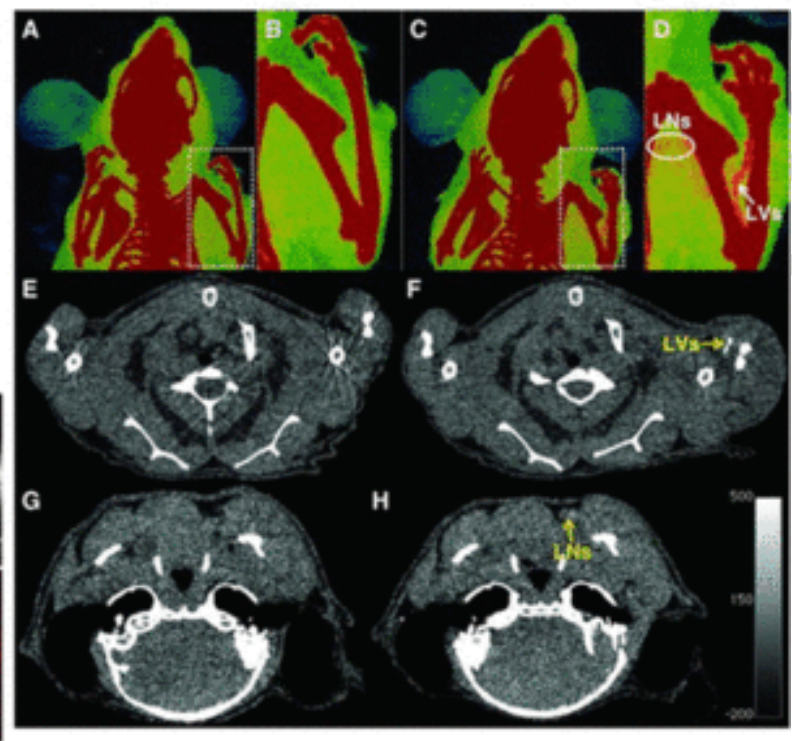

(B)

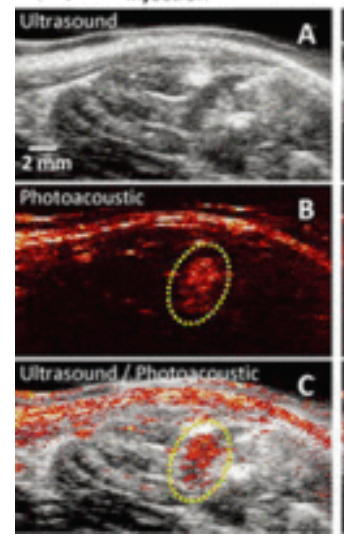

Control

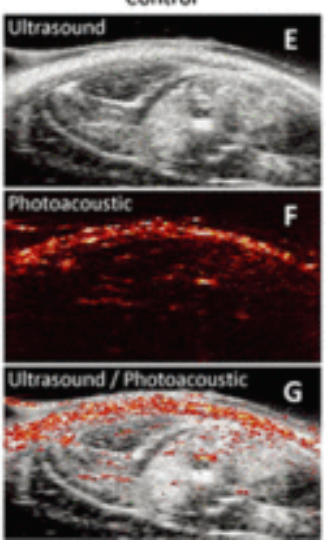

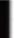

c

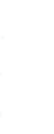

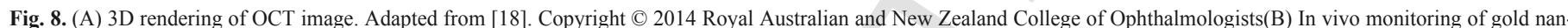

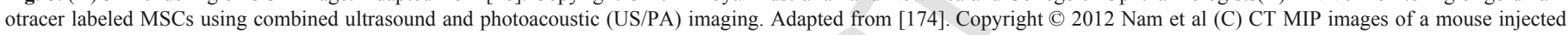

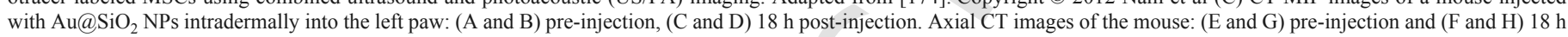
after injection . Adapted from[19]. Copyright (C) 2013 WILEY-VCH Verlag GmbH \& Co. KGaA, Weinheim

eralization capacity of different cell types such as stem cell, osteoblast-like or pre-osteoblast. Cultured in presence of osteogenic media, those cells differentiate in mature osteoblast, as assessed by a high level of alkaline phosphate (ALP) and mineralization, two makers of osteogenesis, and by high level of gene expression. Table 2 summarizes the several studies reporting the possibility of AuNPs to induce cell differentiation into osteogenic, adipogenic lineages [177,173,178-185]. Recently, some reports have emerged pointing out the ability of AuNPs to promote the differentiation of stem cells into osteogenic lineage, making them a powerful system for bone regeneration [177-179,183]. However, the cell proliferation, differentiation and mineralized nodules formation have behaved differently depending on the type of cells, size, surface composition and concentrations of AuNPs. Human adipose-stem cells treated with 1, 5 and $14 \mu \mathrm{g} / \mathrm{mL}$ of AuNPs differentiated in a dose-dependent manner.[178] Liu et al. have investigated the size effect of AuNPs on the proliferation, differentiation and mineralization of a murine pre-osteoblast cell line MC3T3-E1 [179]. After 7 and 14 days of in vitro culturing, the ALP activity and the gene expressions Runx2, BMP-2, ALP and OCN were increased in presence of the both type of particles, however better results were observed with smaller particles. On contrary, human adipose-derived stem cells differentiate faster when incubated with $30 \mathrm{~nm}$ and $50 \mathrm{~nm}$ AuNPs than the one treated with smaller $(15 \mathrm{~nm})$ or bigger (75 and $100 \mathrm{~nm}$ ) AuNPs. [183] Tsai et al. [180] reported that $10 \mathrm{~nm}$ AuNPs in MG63 osteoblast like cells doesnt have any significant role in the osteogenic differentiation. The viability, specific nodule-like phenotype and gene expression were similar to the control.
Various results on the osteogenic process have been reported and a final conclusion of how AuNPs promote the bone formation still remained unclear. Yi et al. [177] have reported that the internalization of $20 \mathrm{~nm}$ AuNPs stimulate osteogenic differentiation in a dosedependent manner, as noticed by an increase of ALP and mineralization quantification with higher AuNPs concentrations (Fig. 9A). It has been suggested that the internalization of AuNPs may act as mechanical stimuli of MSCs that activates p38 mitogen-activated protein kinase (MAPK) pathway (Fig. 9B). On contrary, analogous assays using adipose-inducer media have shown that AuNPs in this case inhibited the adipogenic differentiation due to the down regulation of adipogenesis specific genes. Recently, the surface composition of AuNPs allowed the control of human bone marrow-derived mesenchymal stem cells differentiation (Fig. 9C) [181]. Positively charged amine-modified AuNPs and neutral hydroxyl-modified AuNPs showed no specific effect on the cell behavior, whereas negatively-charged carboxylicAuNPs hampered osteogenesis. When cells were treated with negative AuNPs, the ALP and calcium deposition were reduced, possibly due to an upregulation of FGF- 2 and TGG- $\beta$ expression promoting cell proliferation over osteogenic differentiation. We can also mention that the presence of AuNPs is not always used to enhance cell differentiation, in some cases having a great potential for use in osteoporosis therapy. Sul and co-workers have reported that AuNPs may have a negative effect on the osteoclast formation of bone marrow derived macrophages, stopping thus bone resorption [182]. The antioxidant nature of AuNPs prevented ROS production and the up-regulation of glutathione peroxidase $1(\mathrm{GPx}-1)$, leading to the inhibition of activation of nuclear factor- $\kappa \mathrm{B}$ ligand (RANKL) involved in osteoclastogenesis process. 
Table 2.

Effect of AuNPs for osteogenic and adipogenic differentiation.

\begin{tabular}{|c|c|c|c|c|c|c|}
\hline $\begin{array}{l}\text { Surface } \\
\text { composition }\end{array}$ & $\begin{array}{l}\text { Size } \\
(\mathrm{nm})\end{array}$ & $\begin{array}{l}\text { Supplemented } \\
\text { concentration }\end{array}$ & Cells type & $\begin{array}{l}\text { Cultured } \\
\text { time (days) }\end{array}$ & Observations & Ref. \\
\hline Citrate-AuNPs & 20 & $\begin{array}{l}1 \mathrm{nM} \\
0.2 \mathrm{nM} \\
0.1 \mathrm{nM}\end{array}$ & $\begin{array}{l}\text { Pluripotent } \\
\text { progenitor } \\
\text { Mesenchymal } \\
\text { Stem cells }\end{array}$ & $7,10 \& 14$ & $\begin{array}{l}\text { Promote differentiation in a Dose- and time-dependent manner; } \\
\text { Mechanical stimuli on MSCs to activate MAPK signaling stimuli on MSCs } \\
\text { and induce preferential differentiation; inhibit adipocytic differentiation }\end{array}$ & {$[177]$} \\
\hline Citrate-AuNPs & $\begin{array}{c}20 \\
40\end{array}$ & $\begin{array}{r}0.015 \mathrm{nM} \\
0.03 \mathrm{nM} \\
0.15 \mathrm{nM}\end{array}$ & $\begin{array}{l}\text { Murine Pre- } \\
\text { osteoblast } \\
\text { cell line } \\
\text { MC3T3-E1 }\end{array}$ & $7 \& 14$ & $\begin{array}{l}\text { Promote proliferation, differentiation, mineralization and gene expression in } \\
\text { a Dose- and time-dependent manner; ALP activity and mineralization rate } \\
\text { treated with } 20 \mathrm{~nm} \text { were higher than the one of particles treated with } 40 \mathrm{~nm}\end{array}$ & {$[179]$} \\
\hline Citrate-AuNPs & $\begin{array}{l}15,30 \\
50,75 \\
100\end{array}$ & $1 \mu \mathrm{M}$ & $\begin{array}{l}\text { Human } \\
\text { adipose- } \\
\text { derived stem } \\
\text { cells }\end{array}$ & $7,14 \& 21$ & $\begin{array}{l}\text { All sizes promoted the differentiation of the cells towards osteoblasts; } 30 \mathrm{~nm} \\
\& 50 \mathrm{~nm} \text { exhibits the highest osteogenic differentiation rates; } 50 \mathrm{~nm} \text { GNPs } \\
\text { group expressed the highest ALP level, and mineralization formation }\end{array}$ & {$[183]$} \\
\hline Citrate-AuNPs & 10 & $\begin{array}{l}1 \mathrm{pM} \\
10 \mathrm{pM}\end{array}$ & $\begin{array}{l}\text { MG63 } \\
\text { osteoblast- } \\
\text { like cells }\end{array}$ & $\begin{array}{l}\text { Cells were treated for } 20 \mathrm{~h} \\
\text { with AUNPs; and then } \\
\text { recultured for } 21 \text { days in } \\
\text { fresh medium w/o NPs }\end{array}$ & Have no specific effect on osteogenesis and apoptosis & {$[180]$} \\
\hline $\begin{array}{l}\text { Amine } \\
\text { Caboxyl } \\
\text { Hydroxyl } \\
\text { Citrate } \\
\text { (control) }\end{array}$ & $\begin{array}{l}22 \\
17 \\
12 \\
18\end{array}$ & $0.5 \mathrm{nM}$ & $\begin{array}{l}\text { Human bone- } \\
\text { marrow- } \\
\text { derived } \\
\text { mesenchymal } \\
\text { stem cells }\end{array}$ & 21 days & $\begin{array}{l}\text { Amine, hydroxyl and citrate AuNPs have no effect on osteogenesis; carboxyl } \\
\text { AuNPs reduce ALP activity and matrix mineralization and up-regulate } \\
\text { growth factors FGF- } 2 \text { and TGG- } \beta \text { gene which could promote cells towards } \\
\text { proliferation as well as inhibiting ECM development }\end{array}$ & {$[181]$} \\
\hline $\begin{array}{l}\text { Citrate AuNPs } \\
\text { - embedded in } \\
\text { gelatin } \\
\text { hydrogel } \\
\text { scaffold }\end{array}$ & $27 \pm 3$ & $\begin{array}{l}1,5 \& 14 \mu \mathrm{g} / \\
\mathrm{mL}\end{array}$ & $\begin{array}{l}\text { Human- } \\
\text { adipose stem } \\
\text { cells }\end{array}$ & $4,7,10 \& 14$ days & Promote osteogenesis differentiation in dose \& time dependent manner & {$[178]$} \\
\hline N/A & 150 & $1 \& 2 \mu \mathrm{g} / \mathrm{mL}$ & $\begin{array}{l}\text { Bone morrow } \\
\text { derived } \\
\text { macrophages }\end{array}$ & 3 days & Inhibition of osteoclast formation & {$[182]$} \\
\hline Citrate & $\begin{array}{c}13 \\
45\end{array}$ & & $\begin{array}{l}\text { Human } \\
\text { adipose- } \\
\text { derived } \\
\text { stromal cells }\end{array}$ & & Reduce adipogenesis & {$[184]$} \\
\hline $\begin{array}{l}\text { Citrate } \\
\text { Poly L lysine }\end{array}$ & $\begin{array}{c}20 \\
40 \\
60\end{array}$ & & $\begin{array}{l}\text { Mesenchymal } \\
\text { Stem cells }\end{array}$ & & $\begin{array}{l}\text { Differentiate into adipogenic and osteogenic lineage as measured oil red O } \\
\text { staining and von kossa staining, respectively. }\end{array}$ & {$[173]$} \\
\hline $\begin{array}{l}\text { Gellan gum- } \\
\text { coated AuNRS }\end{array}$ & $47 \times 10$ & $0.05 \mathrm{nM}$ & $\mathrm{SaOS}-2$ & 21 days & $\begin{array}{l}\text { AuNRs-GG combined with osteogenic media enhanced by two fold the } \\
\text { mineralization capacity, as compared to cells exposed to osteogenic media } \\
\text { alone }\end{array}$ & {$[185]$} \\
\hline
\end{tabular}

\subsection{AuNPs-based strategy to enhance scaffolds efficacy}

\subsubsection{AuNPs-based scaffolds for mechanical and cell adhesive} perspectives

The use of scaffold for the regeneration of various tissues (e.g. nerve, cartilage, bone, and cardiac/skeletal muscle) is one of the leading research area in tissue engineering $[5,186,2]$. Scaffolds are biomaterials synthetized with natural polymer (e.g. collagen, polysaccharides, silk fibroin) or semisynthetic polymer (e.g. poly ( $\varepsilon$-caprolactone, PCL) with the aim to mimic the extracellular matrix (ECM) to enhance cell adhesion, migration, proliferation, differentiation, thereby fostering cell function and tissue growth. The ideal material should exhibit properties close to those present in natural tissues: porous 3-D microstructure, biocompatibility, biodegradability at a controlled rate, adequate cell attachment surface, among other [5].

However, researchers are still working on the development of the next generation of scaffold. Due to some limitations such as lack of adhesion sites, poor mechanical structures and lack of electrical conductivity of scaffolds, it is necessary to enhance their structural and mechanical properties. Recently, the incorporation of nanoscale structure into tissue engineering scaffolds have been proposed to facilitate tissue regeneration [8] and may play a key role on affecting the mechanical and adhesive properties of the material, inducing tissue morphogenesis and directing cell self-assembly in 3D [187]. AuNPs have been incorporated to scaffolds and have shown promis- ing features to improve biomaterials mechanical properties $[188,189]$ as well as to promote cell proliferation and differentiation [178]. It also can improve the electrical communication between cardiac cells [13]. Grant and colleagues have developed several scaffolds [190-192] through the crosslinking between polyethylene terephthalate (PET) or collagen with AuNPs, in order to improve the materials degradation rate, which is favorable after implantation, while maintaining an open microstructure. Incorporating AuNPs in a porcine diaphragm resulted in a biocompatible tissue scaffold capable of promoting cell attachment and proliferation while reducing free radicals levels for wound healing [190].

PET meshes are being used as a scaffold implant for hernia repair due to their good mechanical properties. With the purpose of improving its biocompatibility, Whelove et al. have conjugated $20 \mathrm{~nm}$ AuNPs to PET surface [192]. The hybrid materials compared to the pristine one, showed better cell viability and proliferation of L929 fibroblasts with high concentration of particles, and better antimicrobial activity. AuNPs thus can act as free radical scavengers that allow the decrease of ROS and shows surface repellence of Pseudomonas aeruginosa bacteria that make the hybrids scaffold more potential for implantable biomaterial. Later, the same group has reported that the use of $23 \mathrm{~nm}$ AuNPs implied in the formation of collagen scaffold allowed improving scaffolds properties while maintaining an open microstructure. The hybrid materials have shown better resistance against degradation when exposed to collagenase and an enhancement of the biocompatibility. Moreover, with long-term analysis, cel- 

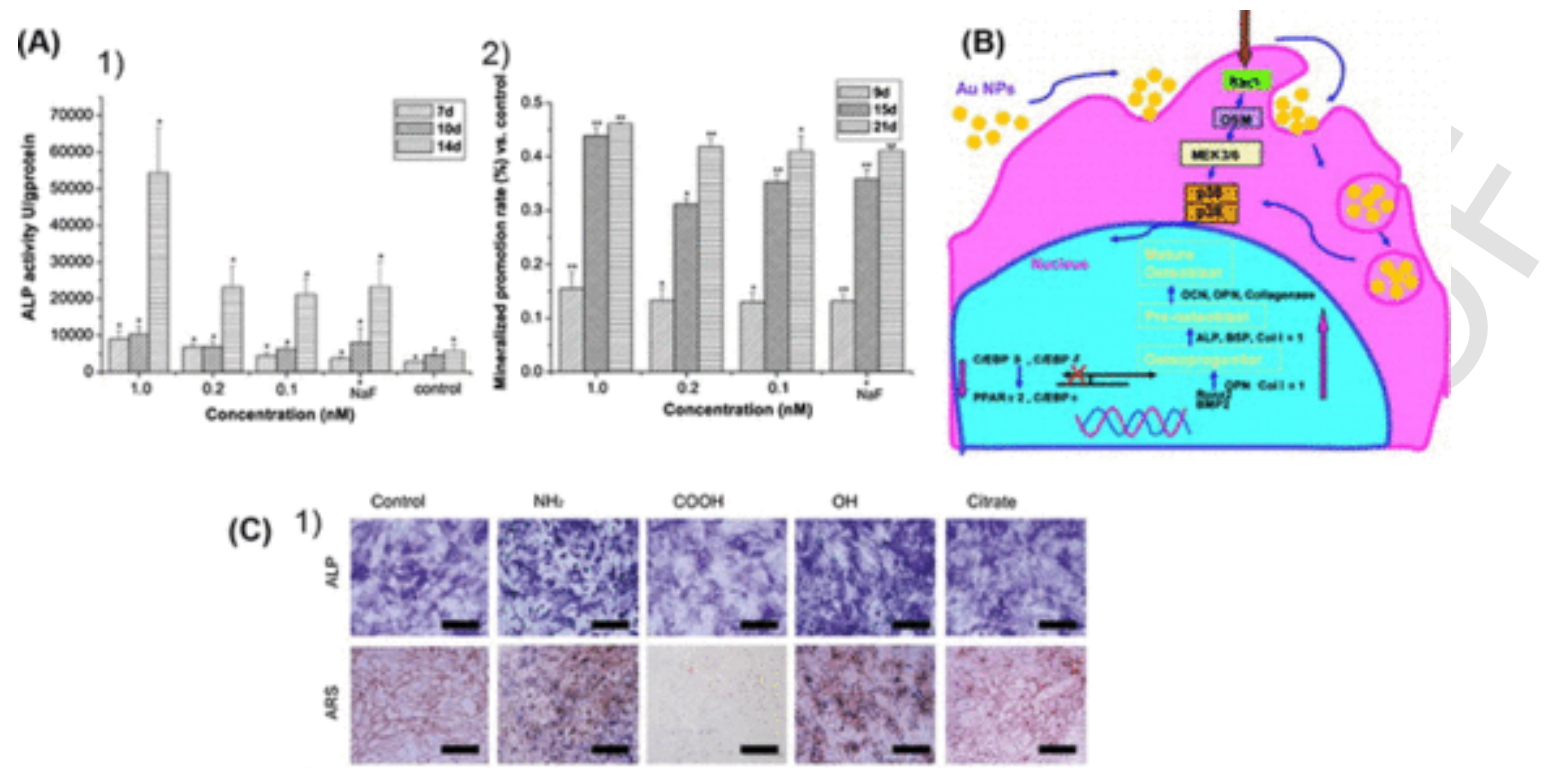

2)

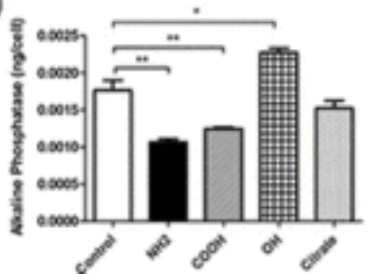

3)

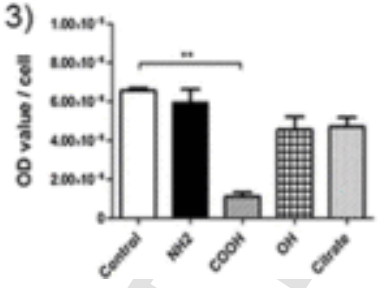

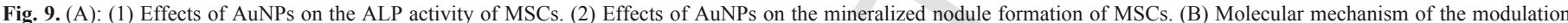

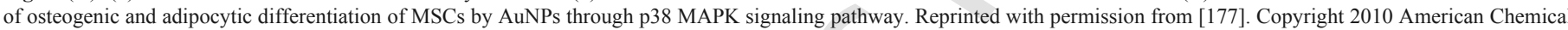

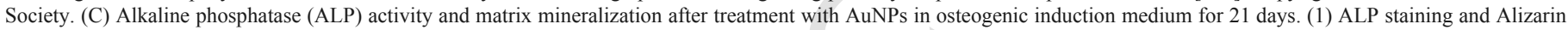
Red S staining. (2) ALP activity assay. (3) Quantification of ARS staining matrix mineralization per well. Adapted from [181], Copyright (2015), with permission from Elsevier.

lular retention, cell proliferation and GAG production were enhanced over the pristine scaffold. The decrease of ROS production was also observed, demonstrating the antioxidant properties of AuNPs that might influence inflammation issue in vivo.

After a heart attack, cardiomyocytes, electrically responsive cells, are cultured within a porous scaffold to grow and assemble into cardiac tissues. However, because of the poor conductivity of biomaterials, engineering a scaffold that generates electrical stimuli is attractive in order to improve electrical communication between adjacent cardiac cells [13]. In order to address this issue, some groups have incorporated AuNPs, because of their electrical properties, within polymeric scaffold. For example, You et al. have prepared a hybrid hydrogel scaffold composed of AuNPs and polymeric gel [193]. Cardiac cells, seeded in the hybrid scaffold, exhibited increased expression of connexin 43 (Cx43), a protein located between cardiac cells and responsible for electrical signal transfer. Likewise, Dvirś group has reported several works incorporated gold compounds within threedimensional cardiac patches such as alginate [194], coiled PCL fiber [195], PCL-gelatin fibrous [196] and decellularized matrices [197] in order to promote cardiac cell-cell interactions, and therefore enhance the formation of cardiac tissue. Shevach et al. reported that the presence of AuNPs allowed the cells to assembled into a more elongated and aligned tissues, enhancing the overall contractility of the engineered tissue [196]. The AuNPs on the PCL-gelatin fibers were able to maintain the ratio of cardiomyocytes to fibroblasts in the culture, to encourage the growth of cardiomyocytes with significantly higher aspect ratio, and promote massive cardiac sarcomeric actinin expression. Finally, engineering cardiac tissues within AuNPs-based scaffolds exhibited significantly higher contraction amplitudes and rates, as compared to nude scaffolds [196,197]. Recently, the same group developed a new nanocomposite scaffold, incorporating AuNPs within coiled electrospun fibers (Fig. 10). Cardiac cells cultured within the hybrid scaffold exhibited an aligned and elongated morphology resembling to the natural morphology of cell bundles in the myocardium [195]. Ravichandran et al. used AuNPs as a crosslinker to stabilize BSA during the preparation of BSA/PVA nanofibers [198]. The presence of AuNPs results on favorable elastic properties of the scaffolds for cardiac tissue regeneration. Then, the combination of AuNPs-loaded nanofibers with 5-azacytidine, a molecule used to induce cardiac differentiation, can enhance the cardiomyogenic differentiation of MSCs, highlighted by an increase of cardiac proteins (actinin, troponin-T and $\mathrm{Cx} 43$ ) expression.

These findings thus emphasize the capability of AuNPs to serve for the development of novel scaffolding strategies.

\subsubsection{AuNPs-based nanosurface topography}

In living systems, cells behavior is greatly influenced by the nanostructured features of the extra-cellular matrix (ECM) component, which should also be the case in TERM. One approach consists on providing nanotopographical cues, with similar effect to that for growth factors, in order to guide cell orientation. To mimic the structure and length scale of natural ECM, nanopatterned surfaces have become rapidly under investigation [199], enabling to control cell morphology, alignment, adhesion, differentiation and cytoskeleton organization. For example, osteogenic differentiation of stem cells has been improved using engineered surface without [200-202] or in synergy with osteogenic inducers [203]. Diverse techniques, including electron-beam lithography [204], photopatterning [205], soft-lith- 

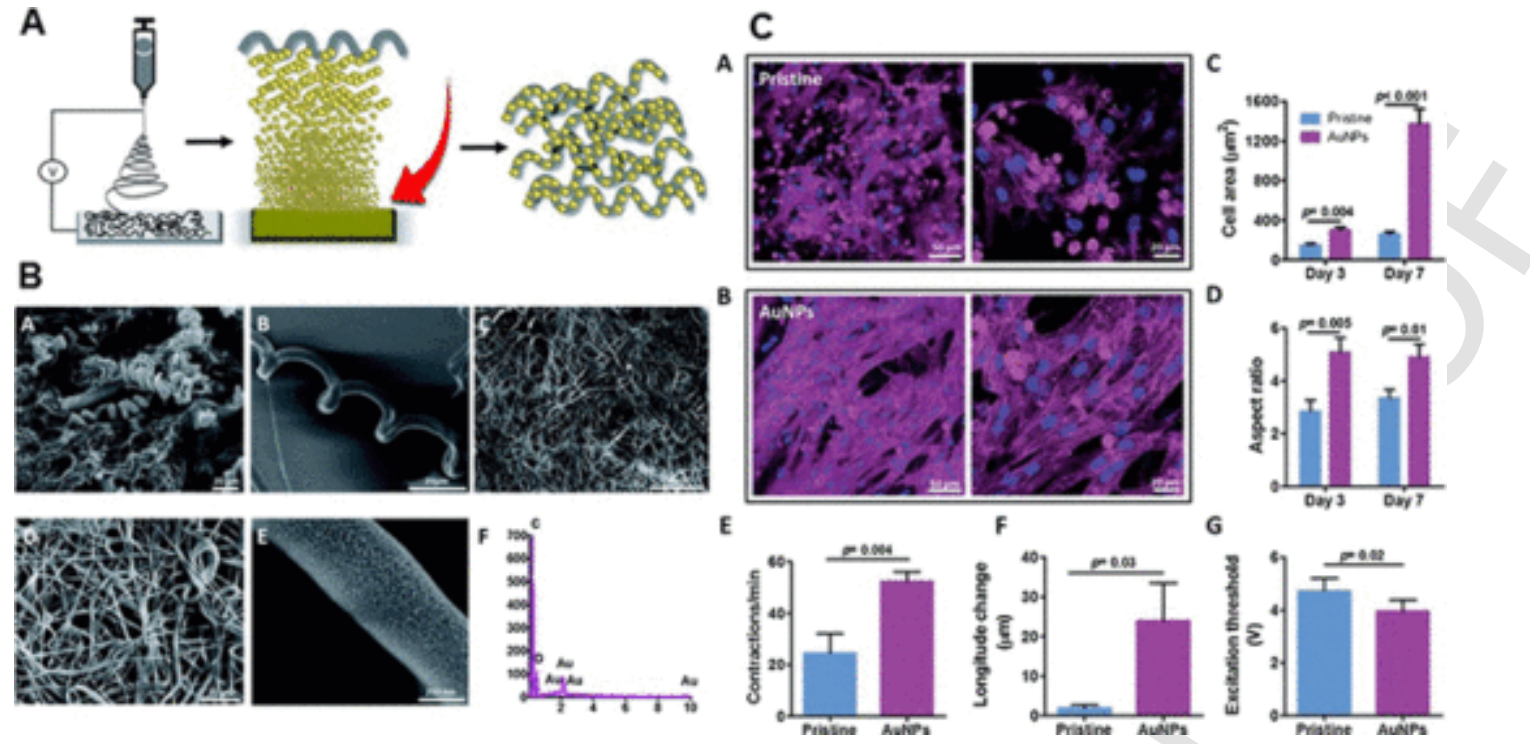

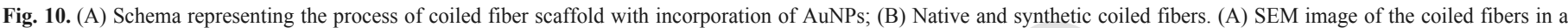

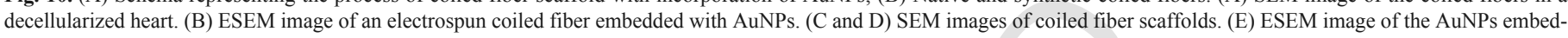

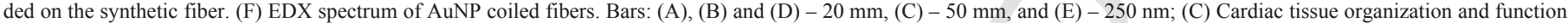

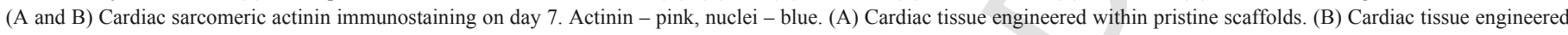

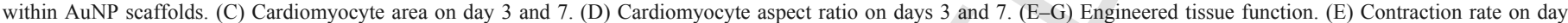

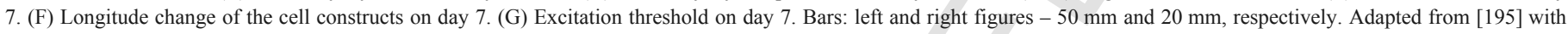
permission of the Royal Society of Chemistry. (For interpretation of the references to colour in this figure legend, the reader is referred to the web version of this article.)

ography [206], nanoimprint lithography [202], have been employed for the development of artificial ECM-based structures.

However, some limitations such poor cell adhesion and cell-surface interactions needs still to be solved. To enhance the efficacy of patterned substrate, AuNPs can be used to control cellular alignment on artificial surfaces. AuNRs have been aligned onto a glass tube via flow assembly to guide the orientation and differentiation of myoblast cells [207]. It has been reported that the height and spatial distance between of AuNPs may affect cell behavior [208]. Three different sizes of NPs $(16,38,68 \mathrm{~nm})$ with a gradient of NPs density have been deposited onto a substrate. The $16 \mathrm{~nm}$ AuNPs enhanced cell adhesion and number of 3 T3 fibroblast and MG63 osteoblast cells than flat substrate, with the best results with a surface density of 50 and 140 particles per $\mu \mathrm{m}^{2}$.

Moreover, prevention of nonspecific adsorption of proteins coupled with adhesion of cells on surfaces is crucial for tissue engineered scaffolding applications. By it turns, Rotelloś group has investigated the cell behavior of mouse embryonic fibroblast cells NIH3T3 onto charged and uncharged AuNPs-deposited polyethylene imine (PEI) substrate [209]. Their findings have demonstrated that the presence of AuNPs decreased protein adsorption and improved cell adhesion and viability, compared to PEI substrate. In addition, patterned PEI lines (300 nm wide, $100 \mathrm{~nm}$ high) on surface via nanoimprint lithography encouraged cells alignment. Moreover, the immobilization of negatively charged AuNPs on the surface of PEI lines provided a higher degree of cellular alignment and evenly spread NIH3T3 cell growth in the direction of the patterns. This behavior can be explained due to the non-fouling properties of the AuNPs coated surfaces and effective communication between the surface and the cells.

In the concept of TERM, cells guidance nanotopography needs to be extended/adapted to more challenging 3D structures. Thus, AuNPs have been incorporated in 3D silk electrospun nanofiber matrix (SNF) and then functionalized with specifically an integrin-binding cell adhesive peptide, arginine-glycineaspartic acid motif (RGD) [188]. The presence of AuNPs within SNF and SNF-RGD allowed to increase cellular spreading, cell adhesion and cell density compared their respective controls (SNF and RGD-SNF).

\section{Final remarks, future trends and challenges}

AuNPs represent a promising tool for TERM. They are particularly advantageous since they are able to deliver bioactive molecule, to diagnose stem cell differentiation status and to track implanted cells, while enhancing stem cell differentiation, adhesive and mechanical properties of scaffolds, and cell-cell interactions. However, AuNPsmediated tissue engineering strategies still represent a great challenge. Some questions may be raised and definitely needs to be answered before eventual translation to clinical applications. The unreliable results related to the interaction between cell and AuNPs have to be definitely clarified. Whereas it has been stipulating that AuNPs contributed to higher production of ROS, which is unbeneficial for cells, more recently it was reported that ROS production is decreased when AuNPs are incorporated within scaffolds. In addition, it has been discussed that AuNPs can stimulate osteogenesis differentiation of stem cells, while inhibiting adipogenic differentiation. And thus, it is difficult to prognostic how the cells will respond in contact with AuNPs. The future trends are thus now to combine all required in vivo and in vitro assays in a long-term study to be able to end up with standardized protocols, e.g. defining appropriate cell type, optimized AuNPs dose, and relevant cytotoxicity assays. Moreover, recently there is a huge effort to develop $3 \mathrm{D}$ artificial vascularized tissue in cancer research in order to recreate the human tissue environment. Thus, as an alternative to $2 \mathrm{D}$ culture and animals, this approach have a great potential to determine and really understand what happen and what will happen in the body when the cells are cultured with AuNPs. In addition, this new strategy might give more information regarding the biodistribution and elimination of AuNPs from the body (process still poorly understood). There is no doubt of the potential of using AuNPs in nanomedicine, as suggested by the on-going clinical trials for AuNPs-based cancer therapy system such as Au- 
rImmune $^{\mathrm{TM}}$ and AuroShell ${ }^{\mathrm{TM}}$. In addition, with the great interest of using AuNPs in nanomedicine, most of these challenges will continue to be addressed in the upcoming research studies.

\section{Acknowledgements}

The authors would like to thank QREN (ON.2 NORTE-01-0124-FEDER-000018) co-financed by North Portugal Regional Operational Program (ON.2 - O Novo Norte), under the National Strategic Reference Framework (NSRF), through the European Regional Development Fund (ERDF) for providing financial support to this project. The Portuguese Foundation for Science and Technology (FCT) distinction attributed to J.M. Oliveira under the FCT Investigator program (IF/00423/2012) is also greatly acknowledged. The authors also thank the financial support provided under the ERC funded project ComplexiTE (Grant ERC-2012-ADG_20120216-321266).

\section{References}

[1] F. Berthiaume, T.J. Maguire, M.L. Yarmush, Tissue engineering and regenerative medicine: history, progress, and challenges, Annu. Rev. Chem. Biomol. Eng. 2 (2011) 403-430, http://dx.doi.org/10.1146/annurevchembioeng-061010-114257.

[2] A.J. Salgado, J.M. Oliveira, A. Martins, F.G. Teixeira, N.A. Silva, N.M Neves, et al., Tissue engineering and regenerative medicine: past, present, and future, Int. Rev. Neurobiol. 108 (2013) 1-33, http://dx.doi.org/10.1016 B978-0-12-410499-0.00001-0.

[3] S.I. Correia, H. Pereira, J. Silva-Correia, C.N. Van Dijk, J. EspregueiraMendes, J.M. Oliveira, et al., Current concepts: tissue engineering and regenerative medicine applications in the ankle joint, J. R. Soc. Interface 11 (2014) 20130784, http://dx.doi.org/10.1098/rsif.2013.0784.

[4] R.S. Tuan, G. Boland, R. Tuli, Adult mesenchymal stem cells and cell-based tissue engineering, Arthritis Res. Ther. 5 (2003) 32-45, http://dx.doi.org/10. 1186/ar614.

[5] F.J. O'Brien, Biomaterials \& scaffolds for tissue engineering, Mater. Today 14 (2011) 88-95, http://dx.doi.org/10.1016/S1369-7021(11)70058-X.

[6] S. Tada, T. Kitajima, Y. Ito, Design and synthesis of binding growth factors, Int. J. Mol. Sci. 13 (2012) 6053-6072, http://dx.doi.org/10.3390/ ijms 13056053 .

[7] M.C. Roco, Nanotechnology: convergence with modern biology and medicine, Curr. Opin. Biotechnol. 14 (2003) 337-346, http://dx.doi.org/10.1016/ S0958-1669(03)00068-5.

[8] L. Zhang, T.J. Webster, Nanotechnology and nanomaterials: promises for improved tissue regeneration, Nano Today 4 (2009) 66-80, http://dx.doi.org/10. 1016/j.nantod.2008.10.014

[9] V. Morigi, A. Tocchio, C. Bellavite Pellegrini, J.H. Sakamoto, M. Arnone, E. Tasciotti, Nanotechnology in medicine: from inception to market domination, J. Drug Deliv. 2012 (2012) 1-7, http://dx.doi.org/10.1155/2012/389485.

[10] S.K. Sahoo, S. Parveen, J.J. Panda, The present and future of nanotechnology in human health care, Nanomedicine Nanotechnology, Biol. Med. 3 (2007) 20-31, http://dx.doi.org/10.1016/j.nano.2006.11.008.

[11] A. Tautzenberger, A. Kovtun, A. Ignatius, Nanoparticles and their potential for application in bone, Int. J. Nanomed. 7 (2012) 4545-4557, http://dx.doi.org/10. 2147/IJN.S34127.

[12] R. Sensenig, Y. Sapir, C. MacDonald, S. Cohen, B. Polyak, Magnetic nanoparticle-based approaches to locally target therapy and enhance tissue regeneration in vivo, Nanomedicine (Lond) 7 (2012) 1425-1442, http://dx.doi.org/10 2217/nnm.12.109.

[13] S. Fleischer, T. Dvir, Tissue engineering on the nanoscale: lessons from the heart, Curr. Opin. Biotechnol. 24 (2013) 664-671, http://dx.doi.org/10.1016/j. copbio.2012.10.016

[14] V.E. Santo, M.T. Rodrigues, M.E. Gomes, Contributions and future perspectives on the use of magnetic nanoparticles as diagnostic and therapeutic tools in the field of regenerative medicine, Expert Rev. Mol. Diagn. 13 (2013) 553-566, http://dx.doi.org/10.1586/14737159.2013.819169.

15] T.M. Sun, Y.C. Wang, F. Wang, J.Z. Du, C.Q. Mao, C.Y. Sun, et al., Cance stem cell therapy using doxorubicin conjugated to gold nanoparticles via hydrazone bonds, Biomaterials 35 (2014) 836-845, http://dx.doi.org/10.1016/j. biomaterials.2013.10.011.

[16] W.F. Zandberg, A.B.S. Bakhtiari, Z. Erno, D. Hsiao, B.D. Gates, T. Claydon, et al., Photothermal release of small molecules from gold nanoparticles in live cells, Nanomedicine Nanotechnology, Biol. Med. 8 (2012) 908-915, http://dx doi.org/10.1016/j.nano.2011.10.012.
[17] T.L. Halo, K.M. McMahon, N.L. Angeloni, Y. Xu, W. Wang, A.B. Chinen, et al., NanoFlares for the detection, isolation, and culture of live tumor cells from human blood, Proc. Natl. Acad. Sci. 111 (2014) 17104-17109, http://dx. doi.org/10.1073/pnas.1418637111

[18] A. de la Zerda, S. Prabhulkar, V.L. Perez, M. Ruggeri, A.S. Paranjape, F. Habte, et al., Optical coherence contrast imaging using gold nanorods in living mice eyes, Clin. Exp. Ophthalmol. (2014) http://dx.doi.org/10.1111/ceo.12299.

[19] K. Hayashi, M. Nakamura, K. Ishimura, Near-infrared fluorescent silica-coated gold nanoparticle clusters for X-ray computed tomography/optical dual modal imaging of the lymphatic system, Adv. Healthc. Mater. 2 (2013) 756-763, http://dx.doi.org/10.1002/adhm.201200238.

[20] X. Huang, M.A. El-Sayed, Gold nanoparticles: optical properties and implementations in cancer diagnosis and photothermal therapy, J. Adv Res. 1 (2010) 13-28, http://dx.doi.org/10.1016/j.jare.2010.02.002.

[21] J. Kimling, M. Maier, B. Okenve, V. Kotaidis, H. Ballot, A. Plech, Turkevich method for gold nanoparticle synthesis revisited, J. Phys. Chem. B 110 (2006) 15700-15707, http://dx.doi.org/10.1021/jp061667w.

[22] S.D. Perrault, W.C.W. Chan, Synthesis and surface modification of highly monodispersed, spherical gold nanoparticles of 50-200 nm, J. Am. Chem. Soc. 131 (2009) 17042-17043, http://dx.doi.org/10.1021/ja907069u.

[23] J. Perezjuste, I. Pastorizasantos, L. Lizmarzan, P. Mulvaney, Gold nanorods: synthesis, characterization and applications, Coord. Chem. Rev. 249 (2005) 1870-1901, http://dx.doi.org/10.1016/j.ccr.2005.01.030.

[24] H.-Y. Wu, H.-C. Chu, T.-J. Kuo, C.-L. Kuo, M.H. Huang, Seed-mediated synthesis of high aspect ratio gold nanorods with nitric acid, Chem. Mater. 17 (2005) 6447-6451, http://dx.doi.org/10.1021/cm051455w.

[25] Y. Huang, A.R. Ferhan, Y. Gao, A. Dandapat, D.-H. Kim, High-yield synthesis of triangular gold nanoplates with improved shape uniformity, tunable edge length and thickness, Nanoscale 6 (2014) 6496-6500, http://dx.doi.org/10. $1039 / \mathrm{c} 4 \mathrm{nr} 00834 \mathrm{k}$

[26] C.J. Huang, P.H. Chiu, Y.H. Wang, C.F. Yang, Synthesis of the gold nanodumbbells by electrochemical method, J. Colloid Interface Sci. 303 (2006) 430-436, http://dx.doi.org/10.1016/j.jcis.2006.07.073.

[27] S. Barbosa, A. Agrawal, L. Rodríguez-Lorenzo, I. Pastoriza-Santos, R.A. Alvarez-Puebla, A. Kornowski, et al., Tuning size and sensing properties in colloidal gold nanostars, Langmuir 26 (2010) 14943-14950, http://dx.doi.org/10 1021/la102559e.

[28] L. Minati, F. Benetti, A. Chiappini, G. Speranza, One-step synthesis of starshaped gold nanoparticles, Colloids Surfaces A Physicochem. Eng. Asp. 441 (2014) 623-628, http://dx.doi.org/10.1016/j.colsurfa.2013.10.025.

[29] S.E. Skrabalak, J. Chen, Y. Sun, X. Lu, L. Au, C.M. Cobley, et al., Gold nanocages: synthesis, properties, and applications, Acc. Chem. Res. 41 (2008) 1587-1595, http://dx.doi.org/10.1021/ar800018v.

[30] M. Grzelczak, J. Pérez-Juste, P. Mulvaney, L.M. Liz-Marzán, Shape control in gold nanoparticle synthesis, Chem. Soc. Rev. 37 (2008) 1783-1791, http://dx. doi.org/10.1039/b711490g.

[31] N. Li, P. Zhao, D. Astruc, Anisotropic gold nanoparticles: synthesis, properties, applications, and toxicity, Angew. Chem. Int. Ed. Engl. 53 (2014) 1756-1789, http://dx.doi.org/10.1002/anie.201300441.

[32] J. Turkevich, P.C. Stevenson, J. Hillier, A study of the nucleation and growth processes in the synthesis of colloidal gold, Discuss. Faraday Soc. (1951) 55 , http://dx.doi.org/10.1039/DF9511100055.

[33] G. Frens, Controlled nucleation for the regulation of the particle size in monodisperse gold suspensions, Nat. Phys. Sci. 241 (1973) 20-22, http://dx. doi.org/10.1038/physci241020a0.

[34] N.R. Jana, L. Gearheart, C.J. Murphy, Wet chemical synthesis of high aspect ratio cylindrical gold nanorods, J. Phys. Chem. B 105 (2001) 4065-4067, http:/ /dx.doi.org/10.1021/jp0107964.

[35] B. Nikoobakht, M.A. El-Sayed, Preparation and growth mechanism of gold nanorods (NRs) using seed-mediated growth method, Chem. Mater. 15 (2003) 1957-1962, http://dx.doi.org/10.1021/cm0207321

[36] E. Filippo, A. Serra, A. Buccolieri, D. Manno, Green synthesis of silver nanoparticles with sucrose and maltose: morphological and structural characterization, J. Non Cryst. Solids 356 (2010) 344-350, http://dx.doi.org/10.1016/ j.jnoncrysol.2009.11.021.

[37] P. Raveendran, J. Fu, S.L. Wallen, Completely "Green" synthesis and stabilization of metal nanoparticles, J. Am. Chem. Soc. 125 (2003) 13940-13941, http://dx.doi.org/10.1021/ja029267j.

[38] F. Khan, S.R. Ahmad, Polysaccharides and their derivatives for versatile tissue engineering application, Macromol. Biosci. 13 (2013) 395-421, http://dx.doi. org/10.1002/mabi.201200409.

[39] J.T. Oliveira, L. Martins, R. Picciochi, P.B. Malafaya, R.A. Sousa, N.M. Neves, et al., Gellan gum: a new biomaterial for cartilage tissue engineering applications, J. Biomed. Mater. Res. - Part A 93 (2010) 852-863, http://dx.doi. org/10.1002/jbm.a.32574.

[40] L.P. Yan, Y.J. Wang, L. Ren, G. Wu, S.G. Caridade, J.B. Fan, et al., Genipincross-linked collagen/chitosan biomimetic scaffolds for articular cartilage tissue engineering applications, J. Biomed. Mater. Res. - Part A 95 A (2010) 465-475, http://dx.doi.org/10.1002/jbm.a.32869. 
[41] H. Huang, X. Yang, Synthesis of polysaccharide-stabilized gold and silver nanoparticles: A green method, Carbohydr. Res. 339 (2004) 2627-2631, http:// dx.doi.org/10.1016/j.carres.2004.08.005.

[42] D.R. Bhumkar, H.M. Joshi, M. Sastry, V.B. Pokharkar, Chitosan reduced gold nanoparticles as novel carriers for transmucosal delivery of insulin, Pharm. Res. 24 (2007) 1415-1426, http://dx.doi.org/10.1007/s11095-007-9257-9.

[43] M. Potara, D. Maniu, S. Astilean, The synthesis of biocompatible and SERSactive gold nanoparticles using chitosan, Nanotechnology 20 (2009) 315602 , http://dx.doi.org/10.1088/0957-4484/20/31/315602.

[44] N. Yang, W.-H. Li, Preparation of gold nanoparticles using chitosan oligosaccharide as a reducing and capping reagent and their in vitro cytotoxic effect on human fibroblasts cells, Mater. Lett. 138 (2015) 154-157, http://dx.doi.org/10. 1016/j.matlet.2014.09.078.

[45] C. Wu, D. Chen, Facile green synthesis of gold nanoparticles with gum arabic as a stabilizing agent and reducing agent, Giold Bull. 43 (2010) 234-240.

[46] V. Kattumuri, K. Katti, S. Bhaskaran, E.J. Boote, S.W. Casteel, G.M. Fent, et al., Gum arabic as a phytochemical construct for the stabilization of gold nanoparticles: in vivo pharmacokinetics and X-ray-contrast-imaging studies, Small 3 (2007) 333-341, http://dx.doi.org/10.1002/smll.200600427.

[47] S. Dhar, V. Mali, S. Bodhankar, A. Shiras, B.L.V. Prasad, V. Pokharkar, Biocompatible gellan gum-reduced gold nanoparticles: cellular uptake and subacute oral toxicity studies, J. Appl. Toxicol. 31 (2011) 411-420, http://dx.doi. org/10.1002/jat.1595.

[48] S. Dhar, E.M. Reddy, A. Prabhune, V. Pokharkar, A. Shiras, B.L.V. Prasad, Cytotoxicity of sophorolipid-gellan gum-gold nanoparticle conjugates and their doxorubicin loaded derivatives towards human glioma and human glioma stem cell lines, Nanoscale 3 (2011) 575-580, http://dx.doi.org/10.1039/c0nr00598c.

[49] S. Pandey, G.K. Goswami, K.K. Nanda, Green synthesis of polysaccharide/ gold nanoparticle nanocomposite: an efficient ammonia sensor, Carbohydr. Polym. 94 (2013) 229-234, http://dx.doi.org/10.1016/j.carbpol.2013.01.009.

[50] D. Pooja, S. Panyaram, H. Kulhari, S.S. Rachamalla, R. Sistla, Xanthan gum stabilized gold nanoparticles: characterization, biocompatibility, stability and cytotoxicity, Carbohydr. Polym. 110 (2014) 1-9, http://dx.doi.org/10.1016/j. carbpol.2014.03.041.

[51] D. Pooja, S. Panyaram, H. Kulhari, B. Reddy, S.S. Rachamalla, R. Sistla, Natural polysaccharide functionalized gold nanoparticles as biocompatible drug delivery carrier, Int. J. Biol. Macromol. 80 (2015) 48-56, http://dx.doi.org/10. 1016/j.ijbiomac.2015.06.022.

[52] K. Yang, X. Wang, Z. Zhou, J. Xu, J. Weng, Q. Zhang, One-step synthesis and characterisation of chitosan-mediated micro-sized gold nanoplates through a thermal process, IET Nanobiotechnol. 1 (2007) 107-111, http://dx.doi.org/10. 1049/iet-nbt:20070018

[53] L. Jia, L. Guo, J. Zhu, Y. Ma, Stability and cytocompatibility of silk fibroincapped gold nanoparticles, Mater. Sci. Eng. C 43 (2014) 231-236, http://dx. doi.org/10.1016/j.msec.2014.07.024.

[54] M.P. Neupane, S.J. Lee, I.S. Park, M.H. Lee, T.S. Bae, Y. Kuboki, et al., Synthesis of gelatin-capped gold nanoparticles with variable gelatin concentration, J. Nanoparticle Res. 13 (2011) 491-498, http://dx.doi.org/10.1007/ s11051-010-9971-9.

[55] S. Suarasan, M. Focsan, O. Soritau, D. Maniu, S. Astilean, One-pot, green synthesis of gold nanoparticles by gelatin and investigation of their biological effects on osteoblast cells, Colloids Surf. B Biointerf. 132 (2015) 122-131, http: /dx.doi.org/10.1016/j.colsurfb.2015.05.009.

[56] S. Aryal, K.C.R. Bahadur, S.R. Bhattarai, P. Prabu, H.Y. Kim, Immobilization of collagen on gold nanoparticles: preparation, characterization, and hydroxyapatite growth, J. Mater. Chem. 16 (2006) 4642, http://dx.doi.org/10.1039/ b608300e.

[57] K. Kumari, P. Singh, G.K. Mehrotra, A facile one pot synthesis of collagen protected gold nanoparticles using Na-malanodialdehyde, Mater. Lett. 79 (2012) 199-201, http://dx.doi.org/10.1016/j.matlet.2012.04.001.

[58] P.M. Tiwari, K. Vig, V.A. Dennis, S.R. Singh, Functionalized gold nanoparticles and their biomedicala applications, Nanomaterials 1 (2011) 31-63, http:// dx.doi.org/10.3390/nano1010031.

[59] R.A. Sperling, W.J. Parak, Surface modification, functionalization and bioconjugation of colloidal inorganic nanoparticles, Philos. Trans. A. Math. Phys. Eng. Sci. 368 (2010) 1333-1383, http://dx.doi.org/10.1098/rsta.2009.0273.

[60] S. Vial, D. Nykypanchuk, K.G. Yager, A.V. Tkachenko, O. Gang, Linear mesostructures in DNA-nanorod self-assembly, ACS Nano 7 (2013) 5437-5445, http://dx.doi.org/10.1021/nn401413b.

[61] D. Zheng, D.A. Giljohann, D.L. Chen, M.D. Massich, X.-Q. Wang, H. Iordanov, et al., Topical delivery of siRNA-based spherical nucleic acid nanoparticle conjugates for gene regulation, Proc. Natl. Acad. Sci. 109 (2012) 11975-11980, http://dx.doi.org/10.1073/pnas.1118425109.

[62] L.E. Van Vlerken, T.K. Vyas, M.M. Amiji, Poly(ethylene glycol)-modified nanocarriers for tumor-targeted and intracellular delivery, Pharm. Res. 24 (2007) 1405-1414, http://dx.doi.org/10.1007/s11095-007-9284-6.

[63] X. Liu, N. Huang, H. Li, H. Wang, Q. Jin, J. Ji, Multidentate polyethylene glycol modified gold nanorods for in vivo near-infrared photothermal cancer therapy, ACS Appl. Mater. Interfaces 6 (2014) 5657-5668, http://dx.doi.org/10. 1021/am5001823.
[64] X. Liu, N. Huang, H. Wang, H. Li, Q. Jin, J. Ji, The effect of ligand composition on the in vivo fate of multidentate poly(ethylene glycol) modified gold nanoparticles, Biomaterials 34 (2013) 8370-8381, http://dx.doi.org/10.1016/j. biomaterials.2013.07.059.

[65] R. Ghosh Chaudhuri, S. Paria, Core/shell nanoparticles: classes, properties, synthesis mechanisms, characterization, and applications, Chem. Rev. 112 (2012) 2373-2433, http://dx.doi.org/10.1021/cr100449n.

[66] L.M. Liz-Marzán, M. Giersig, P. Mulvaney, Synthesis of nanosized gold-silica core-shell particles, Langmuir 12 (1996) 4329-4335, http://dx.doi.org/10.1021/ la9601871.

[67] L. Lu, G. Burkey, I. Halaciuga, D.V. Goia, Core-shell gold/silver nanoparticles: synthesis and optical properties, J. Colloid Interface Sci. 392 (2013) 90-95, http://dx.doi.org/10.1016/j.jcis.2012.09.057.

[68] W.H. Eisa, M.F. Zayed, Y.K. Abdel-Moneam, A.M.A. Zeid, Water-soluble gold/polyaniline core/shell nanocomposite: Synthesis and characterization, Synth. Met. 195 (2014) 23-28, http://dx.doi.org/10.1016/j.synthmet.2014.05. 012 .

[69] X. Dong, X. Zou, X. Liu, P. Lu, J. Yang, D. Lin, et al., Temperature-tunable plasmonic property and SERS activity of the monodisperse thermo-responsive composite microgels with core-shell structure based on gold nanorod as core, Colloids Surfaces A Physicochem. Eng. Asp. 452 (2014) 46-50, http://dx.doi. org/10.1016/j.colsurfa.2014.03.090.

[70] R. Guo, L. Zhang, Z. Zhu, X. Jiang, Direct facile approach to the fabrication of chitosan-gold hybrid nanospheres, Langmuir 24 (2008) 3459-3464, http://dx. doi.org/10.1021/la703080j.

[71] J.V. Jokerst, M. Thangaraj, P.J. Kempen, R. Sinclair, S.S. Gambhir, Photoacoustic imaging of mesenchymal stem cells in living mice via silica-coated gold nanorods, ACS Nano 6 (2012) 5920-5930, http://dx.doi.org/10.1021/ nn302042y.

[72] M. Hembury, C. Chiappini, S. Bertazzo, T.L. Kalber, G.L. Drisko, O. Ogunlade, et al., Gold-silica quantum rattles for multimodal imaging and therapy, Proc. Natl. Acad. Sci. (2015) http://dx.doi.org/10.1073/pnas. 1419622112. 201419622.

[73] J. Huang, K.S. Jackson, C.J. Murphy, Polyelectrolyte wrapping layers control rates of photothermal molecular release from gold nanorods, Nano Lett. 12 (2012) 2982-2987, http://dx.doi.org/10.1021/nl3007402.

[74] K.S. Mayya, B. Schoeler, F. Caruso, Preparation and organization of nanoscale polyelectrolyte-coated gold nanoparticles, Adv. Funct. Mater. 13 (2003) 183-188, http://dx.doi.org/10.1002/adfm.200390028.

[75] A. Gole, C.J. Murphy, Polyelectrolyte-coated gold nanorods: synthesis, characterization and immobilization, Chem. Mater. 17 (2005) 1325-1330, http://dx. doi.org/10.1021/cm048297d.

[76] A. Elbakry, A. Zaky, R. Liebl, R. Rachel, A. Goepferich, M. Breunig, Layerby-layer assembled gold nanoparticles for sirna delivery, Nano Lett. 9 (2009) 2059-2064, http://dx.doi.org/10.1021/n19003865.

[77] C.J. Bishop, S.Y. Tzeng, J.J. Green, Degradable polymer-coated gold nanoparticles for co-delivery of DNA and siRNA, Acta Biomater. 11 (2015) 393-403, http://dx.doi.org/10.1016/j.actbio.2014.09.020.

[78] T. Tencomnao, A. Apijaraskul, V. Rakkhithawatthana, S. Chaleawlert-Umpon, N. Pimpa, W. Sajomsang, et al., Gold/cationic polymer nano-scaffolds mediated transfection for non-viral gene delivery system, Carbohydr. Polym. 84 (2011) 216-222, http://dx.doi.org/10.1016/j.carbpol.2010.12.063.

[79] H. Takahashi, T. Niidome, T. Kawano, S. Yamada, Y. Niidome, Surface modification of gold nanorods using layer-by-layer technique for cellular uptake, J. Nanoparticle Res. 10 (2008) 221-228, http://dx.doi.org/10.1007/ s11051-007-9227-5.

[80] B. Masereel, M. Dinguizli, C. Bouzin, N. Moniotte, O. Feron, B. Gallez, et al., Antibody immobilization on gold nanoparticles coated layer-by-layer with polyelectrolytes, J. Nanoparticle Res. 13 (2011) 1573-1580, http://dx.doi.org/ 10.1007/s11051-010-9908-3.

[81] X. Zhao, Q. Huang, Y. Jin, Gold nanorod delivery of LSD1 siRNA induces human mesenchymal stem cell differentiation, Mater. Sci. Eng. C 54 (2015) 142-149, http://dx.doi.org/10.1016/j.msec.2015.05.013.

[82] A.M. Alkilany, P.K. Nagaria, C.R. Hexel, T.J. Shaw, C.J. Murphy, M.D. Wyatt, Cellular uptake and cytotoxicity of gold nanorods: molecular origin of cytotoxicity and surface effects, Small 5 (2009) 701-708, http://dx.doi.org/10. 1002/smll.200801546.

[83] Y. Pan, S. Neuss, A. Leifert, M. Fischler, F. Wen, U. Simon, et al., Size-dependent cytotoxicity of gold nanoparticles, Small 3 (2007) 1941-1949, http://dx. doi.org/10.1002/smll.200700378.

[84] R. Coradeghini, S. Gioria, C.P. García, P. Nativo, F. Franchini, D. Gilliland, et al., Size-dependent toxicity and cell interaction mechanisms of gold nanoparticles on mouse fibroblasts, Toxicol. Lett. 217 (2013) 205-216, http:// dx.doi.org/10.1016/j.toxlet.2012.11.022.

[85] S.J. Soenen, B. Manshian, J.M. Montenegro, F. Amin, B. Meermann, T. Thiron, et al., Cytotoxic effects of gold nanoparticles: a multiparametric study, ACS Nano 6 (2012) 5767-5783, http://dx.doi.org/10.1021/nn301714n. 
[86] P.C. Naha, P. Chhour, D.P. Cormode, Systematic in vitro toxicological screening of gold nanoparticles designed for nanomedicine applications, Toxicol Vitr. 29 (2015) 1445-1453, http://dx.doi.org/10.1016/j.tiv.2015.05.022.

[87] H. Cai, P. Yao, Gold nanoparticles with different amino acid surfaces: serum albumin adsorption, intracellular uptake and cytotoxicity, Colloids Surfaces B Biointerfaces 123 (2014) 900-906, http://dx.doi.org/10.1016/j.colsurfb.2014. 10.042 .

[88] H.K. Patra, S. Banerjee, U. Chaudhuri, P. Lahiri, A.K. Dasgupta, Cell selective response to gold nanoparticles, Nanomedicine Nanotechnology, Biol. Med. 3 (2007) 111-119, http://dx.doi.org/10.1016/j.nano.2007.03.005.

[89] Y. Qiu, Y. Liu, L. Wang, L. Xu, R. Bai, Y. Ji, et al., Surface chemistry and aspect ratio mediated cellular uptake of Au nanorods, Biomaterials 31 (2010) 7606-7619, http://dx.doi.org/10.1016/j.biomaterials.2010.06.051.

[90] A. Manke, L. Wang, Y. Rojanasakul, Mechanisms of nanoparticle-induced oxidative stress and toxicity, Biomed Res. Int. 2013 (2013) http://dx.doi.org/10. 1155/2013/942916.

[91] Y. Tang, Y. Shen, L. Huang, G. Lv, C. Lei, X. Fan, et al., In vitro cytotoxicity of gold nanorods in A549 cells, Environ. Toxicol. Pharmacol. 39 (2015) 871-878, http://dx.doi.org/10.1016/j.etap.2015.02.003.

[92] M.M. Mkandawire, M. Lakatos, a. Springer, a. Clemens, D. Appelhans, U. Krause-Buchholz, et al., Induction of apoptosis in human cancer cells by targeting mitochondria with gold nanoparticles, Nanoscale (2015) 10634-10640, http://dx.doi.org/10.1039/C5NR01483B

[93] G. Zhang, X. Zeng, P. Li, Nanomaterials in cancer-therapy drug delivery system, J. Biomed. Nanotechnol. 9 (2013) 741-750, http://dx.doi.org/10.1166/jbn. 2013.1583.

[94] J.M. Oliveira, N. Kotobuki, A.P. Marques, R.P. Pirraco, J. Benesch, M. Hirose, et al., Surface engineered carboxymethylchitosan/poly(amidoamine) dendrimer nanoparticles for intracellular targeting, Adv. Funct. Mater. 18 (2008) 1840-1853, http://dx.doi.org/10.1002/adfm.200800165.

[95] A. Orza, O. Soriţǎu, C. Tomuleasa, L. Olenic, A. Florea, O. Pana, et al., Reversing chemoresistance of malignant glioma stem cells using gold nanoparticles, Int. J. Nanomed. 8 (2013) 689-702, http://dx.doi.org/10.2147/IJN. S37481.

[96] Y. Cheng, Q. Dai, R.a. Morshed, X. Fan, M.L. Wegscheid, D.a. Wainwright, et al., Blood-brain barrier permeable gold nanoparticles: an efficient delivery platform for enhanced malignant glioma therapy and imaging, Small (2014) http://dx.doi.org/10.1002/smll.201400654.

[97] X. Zhang, J.G. Teodoro, J.L. Nadeau, Intratumoral gold-doxorubicin is effective in treating melanoma in mice, Nanomedicine Nanotechnology, Biol Med. 11 (2015) 1365-1375, http://dx.doi.org/10.1016/j.nano.2015.04.001.

[98] F.R. Maia, M. Barbosa, D.B. Gomes, N. Vale, P. Gomes, P.L. Granja, et al., Hydrogel depots for local co-delivery of osteoinductive peptides and mesenchymal stem cells, J. Control. Release 189 (2014) 158-168, http://dx.doi. org/10.1016/j.jconrel.2014.06.030.

[99] J.M. Oliveira, R.a. Sousa, N. Kotobuki, M. Tadokoro, M. Hirose, J.F. Mano, et al., The osteogenic differentiation of rat bone marrow stromal cells cultured with dexamethasone-loaded carboxymethylchitosan/poly(amidoamine) dendrimer nanoparticles, Biomaterials 30 (2009) 804-813, http://dx.doi.org/10. 1016/j.biomaterials.2008.10.024

[100] R.M. Raftery, E.G. Tierney, C.M. Curtin, S.-A. Cryan, F.J. O'Brien, Development of a gene-activated scaffold platform for tissue engineering applications using chitosan-pDNA nanoparticles on collagen-based scaffolds, J. Control. Release 210 (2015) 84-94, http://dx.doi.org/10.1016/j.jconrel.2015.05.005.

[101] J. Shi, A.R. Votruba, O.C. Farokhzad, R. Langer, Nanotechnology in drug delivery and tissue engineering: from discovery to applications, Nano Lett. 10 (2010) 3223-3230, http://dx.doi.org/10.1021/nl102184c.

[102] F. Fanord, K. Fairbairn, H. Kim, A. Garces, V. Bhethanabotla, V.K. Gupta, Bisphosphonate-modified gold nanoparticles: a useful vehicle to study the treatment of osteonecrosis of the femoral head, Nanotechnology 22 (2011) 035102, http://dx.doi.org/10.1088/0957-4484/22/3/035102.

[103] M. Rahim, S. Iram, M.S. Khan, M.S. Khan, A.R. Shukla, A.K. Srivastava, et al., Glycation-assisted synthesized gold nanoparticles inhibit growth of bone cancer cells, Colloids Surfaces B Biointerfaces (2013) http://dx.doi.org/10. 1016/j.colsurfb.2013.12.008

[104] F. Schulz, D. Lutz, N. Rusche, N.G. Bastús, M. Stieben, M. Höltig, et al., Gold nanoparticles functionalized with a fragment of the neural cell adhesion molecule L1 stimulate L1-mediated functions, Nanoscale 5 (2013) 10605-10617, http://dx.doi.org/10.1039/c3nr02707d

[105] F. Papastefanaki, I. Jakovcevski, N. Poulia, N. Djogo, F. Schulz, T. Martinovic, et al., Intraspinal delivery of polyethylene glycol-coated gold nanoparticles promotes functional recovery after spinal cord injury, Mol. Ther. 23 (2015) 993-1002, http://dx.doi.org/10.1038/mt.2015.50.

[106] S. Kumari, R.P. Singh, Glycolic acid-g-chitosan-gold nanoflower nanocomposite scaffolds for drug delivery and tissue engineering, Int. J. Biol. Macromol. 50 (2012) 878-883, http://dx.doi.org/10.1016/j.ijbiomac.2011.10.014

[107] S. Kumari, R.P. Singh, Glycolic acid-g-chitosan-Pt-Fe3O4 nanoparticles nanohybrid scaffold for tissue engineering and drug delivery, Int. J. Biol. Macromol. 51 (2012) 76-82, http://dx.doi.org/10.1016/j.ijbiomac.2012.01.040.
[108] S. Mura, J. Nicolas, P. Couvreur, Stimuli-responsive nanocarriers for drug delivery, Nat. Mater. 12 (2013) 991-1003, http://dx.doi.org/10.1038/nmat3776.

[109] C.J. Kearney, H. Skaat, S.M. Kennedy, J. Hu, M. Darnell, T.M. Raimondo, et al., Switchable release of entrapped nanoparticles from alginate hydrogels, Adv. Healthc. Mater. (2015) http://dx.doi.org/10.1002/adhm.201500254.

[110] R. Fernandes, N.R. Smyth, O.L. Muskens, S. Nitti, A. Heuer-Jungemann, M.R. Ardern-Jones, et al., Interactions of skin with gold nanoparticles of different surface charge, shape, and functionality, Small 11 (2015) 713-721, http://dx.doi. org/10.1002/smll.201401913.

[111] A.T. Qureshi, A. Doyle, C. Chen, D. Coulon, V. Dasa, F. Del Piero, et al., Photoactivated miR-148b-nanoparticle conjugates improve closure of critical size mouse calvarial defects, Acta Biomater. 12 (2015) 166-173, http://dx.doi.org/ 10.1016/j.actbio.2014.10.010.

[112] L.C. Kennedy, L.R. Bickford, N.A. Lewinski, A.J. Coughlin, Y.Hu, E.S. Day, et al., A new era for cancer treatment: gold-nanoparticle-mediated thermal therapies, Small 7 (2011) 169-183, http://dx.doi.org/10.1002/smll.201000134.

[113] A.K. Rengan, A.B. Bukhari, A. Pradhan, R. Malhotra, R. Banerjee, R. Srivastava, et al., In vivo analysis of biodegradable liposome gold nanoparticles as efficient agents for photothermal therapy of cancer, Nano Lett. 15 (2015) 842-848, http:// dx.doi.org/10.1021/nl5045378.

[114] L. Jing, X. Liang, Z. Deng, S. Feng, X. Li, M. Huang, et al., Prussian blue coated gold nanoparticles for simultaneous photoacoustic/CT bimodal imaging and photothermal ablation of cancer, Biomaterials 35 (2014) 5814-5821, http://dx.doi. org/10.1016/j.biomaterials.2014.04.005.

[115] T. Fernandez Cabada, C.S. de Pablo, A.M. Serrano, P. Guerrero Fdel, J.J. Olmedo, M.R. Gomez, Induction of cell death in a glioblastoma line by hyperthermic therapy based on gold nanorods, Int. J. Nanomed. 7 (2012) 1511-1523.

[116] J. Chen, C. Glaus, R. Laforest, Q. Zhang, M. Yang, M. Gidding, et al., Gold nanocages as photothermal transducers for cancer treatment, Small 6 (2010) 811-817, http://dx.doi.org/10.1002/smll.200902216.

[117] A.K. Rengan, G. Kundu, R. Banerjee, R. Srivastava, Gold nanocages as effective photothermal transducers in killing highly tumorigenic cancer cells, Part. Part. Syst. Charact. 31 (2014) 398-405, http://dx.doi.org/10.1002/ppsc.201300173.

[118] S. Mallick, I.-C. Sun, K. Kim, D.K. Yi, Silica coated gold nanorods for imaging and photo-thermal therapy of cancer cells, J. Nanosci. Nanotechnol. 13 (2013) 3223-3229, http://dx.doi.org/10.1166/jnn.2013.7149.

[119] W. Xiong, R. Mazid, L.W. Yap, X. Li, W. Cheng, Plasmonic caged gold nanorods for near-infrared light controlled drug delivery, Nanoscale 6 (2014) 14388-14393, http://dx.doi.org/10.1039/C4NR04400B.

[120] X. Huang, P.K. Jain, I.H. El-Sayed, M.A. El-Sayed, Plasmonic photothermal therapy (PPTT) using gold nanoparticles, Lasers Med. Sci. 23 (2008) 217-228, http://dx.doi.org/10.1007/s10103-007-0470-x

[121] J. Wang, B. Dong, B. Chen, Z. Jiang, H. Song, Selective photothermal therapy for breast cancer with targeting peptide modified gold nanorods, Dalton Trans. 41 (2012) 11134-11144, http://dx.doi.org/10.1039/c2dt31227a

[122] L. Au, D. Zheng, F. Zhou, Z.Y.Li, X. Li, Y. Xia, A quantitative study on the photothermal effect of immuno gold nanocages targeted to breast cancer cells, ACS Nano 2 (2008) 1645-1652, http://dx.doi.org/10.1021/nn800370j.

[123] T. Zhan, P.F. Li, S. Bi, B.A. Dong, H.W. Song, H. Ren, et al, 12P-conjugated PEG-modified gold nanorods combined with near-infrared laser for tumor targeting and photothermal therapy, J. Nanosci. Nanotechnol. 12 (2012) 7198-7205, http://dx.doi.org/10.1166/jnn.2012.6502.

[124] X. Huang, I.H. El-Sayed, W. Qian, M.A. El-Sayed, Cancer cell imaging and photothermal therapy in the near-infrared region by using gold nanorods, J. Am. Chem. Soc. 128 (2006) 2115-2120, http://dx.doi.org/10.1021/ja057254a.

[125] Y.Xu, J. Wang, X. Li, Y. Liu, L. Dai, X. Wu, et al., Selective inhibition of breast cancer stem cells by gold nanorods mediated plasmonic hyperthermia, Biomaterials 35 (2014) 4667-4677, http://dx.doi.org/10.1016/j.biomaterials.2014.02.035.

[126] Z. Wang, Z. Chen, Z. Liu, P. Shi, K. Dong, E. Ju, et al., A multi-stimuli responsive gold nanocage-hyaluronic platform for targeted photothermal and chemotherapy, Biomaterials 35 (2014) 9678-9688, http://dx.doi.org/10.1016/j. biomaterials.2014.08.013.

[127] A.T. Qureshi, W.T. Monroe, V. Dasa, J.M. Gimble, D.J. Hayes, MiR-148bnanoparticle conjugates for light mediated osteogenesis ofhuman adipose stromal/stem cells, Biomaterials 34 (2013) 7799-7810, http://dx.doi.org/10.1016/j. biomaterials.2013.07.004.

[128] S.a. Costa Lima, S. Reis, Temperature-responsive polymeric nanospheres containing methotrexate and gold nanoparticles: a multi-drug system for theranostic in rheumatoid arthritis, Colloids Surfaces B Biointerfaces (2015) 1-10, http://dx. doi.org/10.1016/j.colsurfb.2015.04.048.

[129] H.J. Kim, S.-M. Lee, K.-H. Park, C.H. Mun, Y.-B. Park, K.-H. Yoo, Drug-loaded gold/iron/gold plasmonic nanoparticles for magnetic targeted chemo-photothermal treatment of rheumatoid arthritis, Biomaterials 61 (2015) 95-102, http://dx. doi.org/10.1016/j.biomaterials.2015.05.018.

[130] Y. Tao, E. Ju, Z. Liu, K. Dong, J. Ren, X. Qu, Engineered, self-assembled near-infrared photothermal agents for combined tumor immunotherapy and chemo-photothermal therapy, Biomaterials 35 (2014) 6646-6656, http://dx.doi.org/10. 1016/j.biomaterials.2014.04.073 
[131] J. Park, J. Park, E.J. Ju, S.S. Park, J. Choi, J.H. Lee, et al., Multifunctional hollow gold nanoparticles designed for triple combination therapy and CT imaging, J. Control. Release 207 (2015) 77-85, http://dx.doi.org/10.1016/j.jconrel. 2015.04.007.

[132] R. Mooney, L. Roma, D. Zhao, D. Van Haute, E. Garcia, S.U. Kim, et al., Neural stem cell-mediated intratumoral delivery of gold nanorods improves photothermal therapy, ACS Nano (2014) 12450-12460.

[133] W. Sheng, A.H. Alhasan, G. DiBernardo, K.M. Almutairi, J.P. Rubin, B.E. DiBernardo, et al., Gold nanoparticle-assisted selective photothermolysis of adipose tissue (NanoLipo), Plast. Reconstr. Surgery. Glob. Open. 2 (2014) e283, http://dx.doi.org/10.1097/GOX.0000000000000251.

[134] A. Downes, R. Mouras, A. Elfick, Optical spectroscopy for noninvasive monitoring of stem cell differentiation, J. Biomed. Biotechnol. 2010 (2010) 101864, http://dx.doi.org/10.1155/2010/101864.

[135] M.F. Kircher, S.S. Gambhir, J. Grimm, Noninvasive cell-tracking methods, Nat. Rev. Clin. Oncol. 8 (2011) 677-688, http://dx.doi.org/10.1038/nrclinonc. 2011.141

[136] H. Xu, J. Chen, J. Birrenkott, J.X. Zhao, S. Takalkar, K. Baryeh, et al., Goldnanoparticle-decorated silica nanorods for sensitive visual detection of proteins, Anal. Chem. 86 (2014) 7351-7359, http://dx.doi.org/10.1021/ac502249f.

[137] M.S. Cordray, M. Amdahl, R.R. Richards-Kortum, Gold nanoparticle aggregation for quantification of oligonucleotides: optimization and increased dynamic range, Anal. Biochem. 431 (2012) 99-105, http://dx.doi.org/10.1016/j.ab.2012 09.013.

[138] S. Vial, D. Nykypanchuk, F.L. Deepak, M. Prado, O. Gang, Plasmonic response of DNA-assembled gold nanorods: effect of DNA linker length, temperature and linker/nanoparticles ratio, J. Colloid Interface Sci. 433 (2014) 34-42, http://dx.doi.org/10.1016/j.jcis.2014.07.020.

[139] X. Yang, J. Li, H. Pei, Y. Zhao, X. Zuo, C. Fan, et al., DNA-gold nanoparticle conjugates-based nanoplasmonic probe for specific differentiation of cell types, Anal. Chem. 86 (2014) 3227-3231, http://dx.doi.org/10.1021/ ac500381e.

[140] P.C.R. Adria Neely, Candice Perry, Birsen Varisli, Anant K. Singh, Tahir Arbneshi, Dulal Senapati, Jhansi Rani Kalluri, A. Neely, C. Perry, B. Varisli, A.K.A. Singh, T. Arbneshi, et al., Ultrasensitive and highly selective detection of Alzheimer's disease biomarker using two-photon Rayleigh scattering properties of gold nanoparticle, ACS Nano XXX (2009) 2834-2840, http://dx.doi. org/10.1021/nn900813b.

[141] J.D. Driskell, C.A. Jones, S.M. Tompkins, R.A. Tripp, One-step assay for detecting influenza virus using dynamic light scattering and gold nanoparticles, Analyst 136 (2011) 3083-3090, http://dx.doi.org/10.1039/clan15303j.

[142] C. Wang, J. Irudayaraj, Gold nanorod probes for the detection of multiple pathogens, Small 4 (2008) 2204-2208, http://dx.doi.org/10.1002/smll. 200800309.

[143] A.R. Bizzarri, S. Cannistraro, SERS detection of thrombin by protein recognition using functionalized gold nanoparticles, Nanomedicine 3 (2007) 306-310, http://dx.doi.org/10.1016/j.nano.2007.09.005.

[144] Z. Wang, L. Ma, Gold nanoparticle probes, Coord. Chem. Rev. 253 (2009) 1607-1618, http://dx.doi.org/10.1016/j.ccr.2009.01.005.

[145] S. Suarasan, M. Focsan, D. Maniu, S. Astilean, Gelatin-nanogold bioconjugates as effective plasmonic platforms for SERS detection and tagging, Colloids Surfaces B Biointerfaces 103 (2013) 475-481, http://dx.doi.org/10.1016 j.colsurfb.2012.10.046

[146] T.H. Kim, K.B. Lee, J.W. Choi, 3D graphene oxide-encapsulated gold nanoparticles to detect neural stem cell differentiation, Biomaterials 34 (2013) 8660-8670, http://dx.doi.org/10.1016/j.biomaterials.2013.07.101.

[147] K. Lee, V.P. Drachev, J. Irudayaraj, DNA-gold nanoparticle reversible networks grown on cell surface marker sites: application in diagnostics, ACS Nano 5 (2011) 2109-2117, http://dx.doi.org/10.1021/nn1030862.

[148] J.S. Lee, M.S. Han, C.A. Mirkin, Colorimetric detection of mercuric ion $(\mathrm{Hg} 2+)$ in aqueous media using DNA-functionalized gold nanoparticles, Angew. Chem. - Int. Ed. 46 (2007) 4093-4096, http://dx.doi.org/10.1002/anie 200700269.

[149] C.D. Medley, J.E. Smith, Z. Tang, Y. Wu, S. Bamrungsap, W. Tan, Gold nanoparticle-based colorimetric assay for the direct detection of cancerous cells, Anal. Chem. 80 (2008) 1067-1072, http://dx.doi.org/10.1021/ac702037y

[150] A. Stadler, C. Chi, D. van der Lelie, O. Gang, DNA-incorporating nanomaterials in biotechnological applications, Nanomedicine (Lond) 5 (2010) 319-334, http://dx.doi.org/10.2217/nnm.10.2.

[151] X. Gao, H. Xu, M. Baloda, A.S. Gurung, L.P. Xu, T. Wang, et al., Visual detection of microRNA with lateral flow nucleic acid biosensor, Biosens. Bioelectron. 54 (2014) 578-584, http://dx.doi.org/10.1016/j.bios.2013.10.055.

[152] M. Chen, Z. Yu, D. Liu, T. Peng, K. Liu, S. Wang, et al., Dual gold nanoparticle lateflow immunoassay for sensitive detection of Escherichia coli O157:H7, Anal. Chim. Acta 876 (2015) 71-76, http://dx.doi.org/10.1016/j.aca.2015.03. 023.

[153] A.M. López-Marzo, J. Pons, D.A. Blake, A. Merkoçi, High sensitive goldnanoparticle based lateral flow Immunodevice for $\mathrm{Cd} 2+$ detection in drinking waters, Biosens. Bioelectron. 47 (2013) 190-198, http://dx.doi.org/10.1016/j. bios.2013.02.031

[154] W. Wu, L. Yu, Z. Fang, P. Lie, L. Zeng, A lateral flow biosensor for the detection of human pluripotent stem cells, Anal. Biochem. 436 (2013) 160-164, http://dx.doi.org/10.1016/j.ab.2013.01.034.

[155] W. Wu, Y. Mao, S. Zhao, X. Lu, X. Liang, L. Zeng, Strand displacement amplification for ultrasensitive detection of human pluripotent stem cells, Anal. Chim. Acta (2015) 1-7, http://dx.doi.org/10.1016/j.aca.2015.04.003.

[156] C.K.K. Choi, J. Li, K. Wei, Y.J. Xu, L.W.C. Ho, M. Zhu, et al., A gold@polydopamine core-shell nanoprobe for long-term intracellular detection of micrornas in differentiating stem cells, J. Am. Chem. Soc. (2015) http://dx.doi.org/10. 1021/jacs.5b01457. 150605072506002.

[157] R. Meir, M. Motiei, R. Popovtzer, Gold nanoparticles for in vivo cell tracking, Nanomedicine (Lond) 9 (2014) 2059-2069.

[158] A.A. Appel, M.A. Anastasio, J.C. Larson, E.M. Brey, Imaging challenges in biomaterials and tissue engineering, Biomaterials 34 (2013) 6615-6630, http:// dx.doi.org/10.1016/j.biomaterials.2013.05.033

[159] S. Patskovsky, E. Bergeron, M. Meunier, Hyperspectral darkfield microscopy of PEGylated gold nanoparticles targeting CD44-expressing cancer cells, J. Biophoton. (2013) http://dx.doi.org/10.1002/jbio.201300165.

[160] C. Lalande, S. Miraux, S.M. Derkaoui, S. Mornet, R. Bareille, J.C. Fricain, et al., Magnetic resonance imaging tracking of human adipose derived stromal cells within three-dimensional scaffolds for bone tissue engineering, Eur. Cell. Mater. 21 (2011) 341-354.

[161] H. Xu, S.F. Othman, R.L. Magin, Monitoring tissue engineering using magnetic resonance imaging, J. Biosci. Bioeng. 106 (2008) 515-527, http://dx.doi org/10.1263/jbb.106.515.

[162] M.S.R. Gudur, R.R. Rao, A.W. Peterson, D.J. Caldwell, J.P. Stegemann, C.X. Deng, Noninvasive quantification of in vitro osteoblastic differentiation in $3 \mathrm{D}$ engineered tissue constructs using spectral ultrasound imaging, PLoS ONE 9 (2014) http://dx.doi.org/10.1371/journal.pone.0085749.

[163] N.J. Durr, T. Larson, D.K. Smith, B.A. Korgel, K. Sokolov, A. Ben-Yakar, Two-photon luminescence imaging of cancer cells using molecularly targeted gold nanorods, Nano Lett. 7 (2007) 941-945, http://dx.doi.org/10.1021/ $\mathrm{nl} 062962 \mathrm{v}$

[164] X. Cai, Y.S. Zhang, Y. Xia, L.V. Wang, Photoacoustic microscopy in tissue engineering, Mater. Today 16 (2013) 67-77, http://dx.doi.org/10.1016/j. mattod.2013.03.007.

[165] S.J. Matcher, Practical aspects of OCT imaging in tissue engineering, Methods Mol. Biol. 695 (2011) 261-280, http://dx.doi.org/10.1007/978-1-60761-984-0 17.

[166] A. Giuliani, C. Frati, A. Rossini, V.S. Komlev, C. Lagrasta, M. Savi, et al., High-resolution X-ray microtomography for three-dimensional imaging of cardiac progenitor cell homing in infarcted rat hearts, J. Tissue Eng. Regen. Med. 5 (2011) http://dx.doi.org/10.1002/term.409.

[167] S. Hong, S. Park, J. Park, J. Yi, Effect of end group modification of DNAfunctionalized gold nanoparticles on cellular uptake in HepG2 cells, Colloids Surfaces B Biointerfaces 112 (2013) 415-420, http://dx.doi.org/10.1016/j. colsurfb.2013.08.020

[168] S.C. Boca, M. Potara, F. Toderas, O. Stephan, P.L. Baldeck, S. Astilean, Uptake and biological effects of chitosan-capped gold nanoparticles on Chinese hamster ovary cells, Mater. Sci. Eng. C 31 (2011) 184-189, http://dx.doi.org/ 10.1016/j.msec.2010.08.015.

[169] J.A. Yang, H.T. Phan, S. Vaidya, C.J. Murphy, Nanovacuums: nanoparticle uptake and differential cellular migration on a carpet of nanoparticles, Nano Lett. 13 (2013) 2295-2302, http://dx.doi.org/10.1021/nl400972r.

[170] R. Ahijado-Guzmán, J. Prasad, C. Rosman, A. Henkel, L. Tome, D. Schneider, Plasmonic nanosensors for simultaneous quantification of multiple protein - protein binding affi nities, Nano Lett. 14 (2014) 5528-5532.

[171] W. Lu, Q. Huang, G. Ku, X. Wen, M. Zhou, D. Guzatov, et al., Photoacoustic imaging of living mouse brain vasculature using hollow gold nanospheres, Biomaterials 31 (2010) 2617-2626, http://dx.doi.org/10.1016/j.biomaterials. 2009.12.007.

[172] Y.S. Zhang, Y. Wang, L. Wang, Y. Wang, X. Cai, C. Zhang, et al., Labeling human mesenchymal stem cells with gold nanocages for in vitro and in vivo tracking by two-photon microscopy and photoacoustic microscopy, Theranostics 3 (2013) 532-543, http://dx.doi.org/10.7150/thno.5369.

[173] L.M. Ricles, S.Y. Nam, K. Sokolov, S.Y. Emelianov, L.J. Suggs, Function of mesenchymal stem cells following loading of gold nanotracers, Int. J. Nanomed. 6 (2011) 407-416, http://dx.doi.org/10.2147/IJN.S16354.

[174] S.Y. Nam, L.M. Ricles, L.J. Suggs, S.Y. Emelianov, In vivo ultrasound and photoacoustic monitoring of mesenchymal stem cells labeled with gold nanotracers, PLoS ONE 7 (2012) http://dx.doi.org/10.1371/journal.pone.0037267.

[175] E. Chung, S.Y. Nam, L.M. Ricles, S.Y. Emelianov, L.J. Suggs, Evaluation of gold nanotracers to track adipose-derived stem cells in a PEGylated fibrin gel for dermal tissue engineering applications, Int. J. Nanomed. 8 (2013) 325-336, http://dx.doi.org/10.2147/IJN.S36711

[176] L.E. Cole, T. Vargo-Gogola, R.K. Roeder, Bisphosphonate-functionalized gold nanoparticles for contrast-enhanced X-ray detection of breast microcalcifica- 
tions, Biomaterials 35 (2014) 2312-2321, http://dx.doi.org/10.1016/j. biomaterials.2013.11.077.

[177] C. Yi, D. Liu, C.-C. Fong, J. Zhang, M. Yang, Gold nanoparticles promote osteogenic differentiation of mesenchymal stem cells through p38 MAPK pathway, ACS Nano 4 (2010) 6439-6448, http://dx.doi.org/10.1021/nn101373r.

[178] D.N. Heo, W.-K. Ko, M.S. Bae, J.B. Lee, D.-W. Lee, W. Byun, et al., Enhanced bone regeneration with a gold nanoparticle-hydrogel complex, J. Mater. Chem. B 2 (2014) 1584, http://dx.doi.org/10.1039/c3tb21246g.

[179] D. Liu, J. Zhang, C. Yi, M. Yang, The effects of gold nanoparticles on the proliferation, differentiation, and mineralization function of MC3T3-E1 cells in vitro, Chinese Sci. Bull. 55 (2010) 1013-1019, http://dx.doi.org/10.1007/ s11434-010-0046-1.

[180] S.W. Tsai, J.W. Liaw, Y.C. Kao, M.Y. Huang, C.Y. Lee, L.R. Rau, et al., Internalized gold nanoparticles do not affect the osteogenesis and apoptosis of MG63 osteoblast-like cells: a quantitative, in vitro study, PLoS ONE 8 (2013) http://dx.doi.org/10.1371/journal.pone.0076545.

[181] J.J. Li, N. Kawazoe, G. Chen, Gold nanoparticles with different charge and moiety induce differential cell response on mesenchymal stem cell osteogenesis, Biomaterials 54 (2015) 226-236, http://dx.doi.org/10.1016/j.biomaterials. 2015.03.001.

[182] O.-J. Sul, J.-C. Kim, T.-W. Kyung, H.-J. Kim, Y.-Y. Kim, S.-H. Kim, et al., Gold nanoparticles inhibited the receptor activator of nuclear factor-kb ligand (RANKL)-induced osteoclast formation by acting as an antioxidant, Biosci. Biotechnol. Biochem. 74 (2010) 2209-2213, http://dx.doi.org/10.1271/bbb. 100375 .

[183] W.-K. Ko, D.N. Heo, H.-J. Moon, S.J. Lee, M.S. Bae, J.B. Lee, et al., The effect of gold nanoparticle size on osteogenic differentiation of adipose-derived stem cells, J. Colloid Interface Sci. 438 (2015) 68-76, http://dx.doi.org/10. 1016/j.jcis.2014.08.058

[184] T. Mironava, M. Hadjiargyrou, M. Simon, M.H. Rafailovich, Gold nanoparticles cellular toxicity and recovery: adipose derived stromal cells, Nanotoxicology 8 (2014) 189-201, http://dx.doi.org/10.3109/17435390.2013.769128.

[185] S. Vieira, S. Vial, F.R. Maia, M. Carvalho, R.L. Reis, P.L. Granja, et al., Gellan gum-coated gold nanorods: an intracellular nanosystem for bone tissue engineering, RSC Adv. 5 (2015) 77996-78005, http://dx.doi.org/10.1039/ C5RA13556G.

[186] L.P. Yan, J.M. Oliveira, A.L. Oliveira, S.G. Caridade, J.F. Mano, R.L. Reis, Macro/microporous silk fibroin scaffolds with potential for articular cartilage and meniscus tissue engineering applications, Acta Biomater. 8 (2012) 289-301, http://dx.doi.org/10.1016/j.actbio.2011.09.037.

[187] E. Engel, A. Michiardi, M. Navarro, D. Lacroix, J.A. Planell, Nanotechnology in regenerative medicine: the materials side, Trends Biotechnol. 26 (2008) 39-47, http://dx.doi.org/10.1016/j.tibtech.2007.10.005.

[188] T. Cohen-Karni, K.J. Jeong, J.H. Tsui, G. Reznor, M. Mustata, M. Wanunu, et al., Nanocomposite gold-silk nanofibers, Nano Lett. 12 (2012) 5403-5406, http://dx.doi.org/10.1021/nl302810c.

[189] N.G. Patel, A. Kumar, V.N. Jayawardana, C.D. Woodworth, P.a. Yuya, Fabrication, nanomechanical characterization, and cytocompatibility of gold-reinforced chitosan bio-nanocomposites, Mater. Sci. Eng. C 44 (2014) 336-344, http://dx.doi.org/10.1016/j.msec.2014.08.042.

[190] M.J. Cozad, S.L. Bachman, S.A. Grant, Assessment of decellularized porcine diaphragm conjugated with gold nanomaterials as a tissue scaffold for wound healing, J. Biomed. Mater. Res. - Part A 99 A (2011) 426-434, http://dx.doi. org/10.1002/jbm.a.33182.

[191] S.A. Grant, C.S. Spradling, D.N. Grant, D.B. Fox, L. Jimenez, D.A. Grant, et al., Assessment of the biocompatibility and stability of a gold nanoparticle collagen bioscaffold, J. Biomed. Mater. Res. - Part A 102 (2014) 332-339, http://dx.doi.org/10.1002/jbm.a.34698.

[192] O.E. Whelove, M.J. Cozad, B.D. Lee, S. Sengupta, S.L. Bachman, B.J. Ramshaw, et al., Development and in vitro studies of a polyethylene terephtha- late-gold nanoparticle scaffold for improved biocompatibility, J. Biomed. Mater. Res. - Part B Appl. Biomater. 99 B (2011) 142-149, http://dx.doi.org/ 10.1002/jbm.b.31881

[193] J.O. You, M. Rafat, G.J.C. Ye, D.T. Auguste, Nanoengineering the heart: conductive scaffolds enhance connexin 43 expression, Nano Lett. 11 (2011) 3643-3648, http://dx.doi.org/10.1021/nl201514a.

[194] T. Dvir, B.P. Timko, M.D. Brigham, S.R. Naik, S.S. Karajanagi, O. Levy, et al., Nanowired three-dimensional cardiac patches, Nat. Nanotechnol. 6 (2011) 720-725, http://dx.doi.org/10.1038/nnano.2011.160.

[195] S. Fleischer, M. Shevach, R. Feiner, T. Dvir, Coiled fiber scaffolds embedded with gold nanoparticles improve the performance of engineered cardiac tissues, Nanoscale (2014) http://dx.doi.org/10.1039/c4nr00300d.

[196] M. Shevach, B.M. Maoz, R. Feiner, A. Shapira, T. Dvir, Nanoengineering gold particle composite fibers for cardiac tissue engineering, J. Mater. Chem. B 1 (2013) 5210, http://dx.doi.org/10.1039/c3tb20584c

[197] M. Shevach, S. Fleischer, A. Shapira, T. Dvir, Gold nanoparticle-decellularized matrix hybrids for cardiac tissue engineering, Nano Lett. (2014).

[198] R. Ravichandran, R. Sridhar, J.R. Venugopal, S. Sundarrajan, S. Mukherjee, S. Ramakrishna, Gold nanoparticle loaded hybrid nanofibers for cardiogenic differentiation of stem cells for infarcted myocardium regeneration, Macromol. Biosci. 14 (2014) 515-525, http://dx.doi.org/10.1002/mabi.201300407.

[199] J. Kim, W.G. Bae, K.T. Lim, K.J. Jang, S. Oh, K.J. Jang, et al., Density of nanopatterned surfaces for designing bone tissue engineering scaffolds, Mater. Lett. 130 (2014) 227-231, http://dx.doi.org/10.1016/j.matlet.2014.05.107.

[200] J. Yang, L.E. Mcnamara, N. Gadegaard, E.V. Alakpa, K.V. Burgess, R.M.D, Meek, et al., Nanotopographical induction of osteogenesis through adhesion, bone regulation of microRNAs, ACS Nano (2014) 9941-9953.

[201] J. Fiedler, B. Özdemir, J. Bartholomä, A. Plettl, R.E. Brenner, P. Ziemann, The effect of substrate surface nanotopography on the behavior of multipotnent mesenchymal stromal cells and osteoblasts, Biomaterials 34 (2013) 8851-8859, http://dx.doi.org/10.1016/j.biomaterials.2013.08.010.

[202] M.J. Dalby, N. Gadegaard, R. Tare, A. Andar, M.O. Riehle, P. Herzyk, et al., The control of human mesenchymal cell differentiation using nanoscale symmetry and disorder, Nat. Mater. 6 (2007) 997-1003, http://dx.doi.org/10.1038/ nmat2013

[203] M.-H. You, M.K. Kwak, D.-H. Kim, K. Kim, A. Levchenko, D.-Y. Kim, et al., Synergistically enhanced osteogenic differentiation of human mesenchymal stem cells by culture on nanostructured surfaces with induction media, Biomacromolecules 11 (2010) 1856-1862, http://dx.doi.org/10.1021/ bm100374n.

[204] N. Idota, T. Tsukahara, K. Sato, T. Okano, T. Kitamori, The use of electron beam lithographic graft-polymerization on thermoresponsive polymers for regulating the directionality of cell attachment and detachment, Biomaterials 30 (2009) 2095-2101, http://dx.doi.org/10.1016/j.biomaterials.2008.12.058

[205] S.J. Bryant, J.L. Cuy, K.D. Hauch, B.D. Ratner, Photo-patterning of porous hydrogels for tissue engineering, Biomaterials 28 (2007) 2978-2986, http://dx. doi.org/10.1016/j.biomaterials.2006.11.033.

[206] G. Vozzi, C. Flaim, A. Ahluwalia, S. Bhatia, Fabrication of PLGA scaffolds using soft lithography and microsyringe deposition, Biomaterials 24 (2003) 2533-2540, http://dx.doi.org/10.1016/S0142-9612(03)00052-8.

[207] X. Zan, S. Feng, E. Balizan, Y. Lin, Q. Wang, Facile method for large scale alignment of one dimensional nanoparticles and control over myoblast orientation and differentiation, ACS Nano 7 (2013) 8385-8396, http://dx.doi.org/10. 1021/nn403908k

[208] R.V. Goreham, A. Mierczynska, L.E. Smith, R. Sedev, K. Vasilev, Small surface nanotopography encourages fibroblast and osteoblast cell adhesion, RSC Adv. 3 (2013) 10309, http://dx.doi.org/10.1039/c3ra23193c.

[209] C. Subramani, K. Saha, B. Creran, A. Bajaj, D.F. Moyano, H. Wang, et al., Cell alignment using patterned biocompatible gold nanoparticle templates, Small 8 (2012) 1209-1213, http://dx.doi.org/10.1002/smll.201102405. 